\title{
Athenacrinus n. gen. and other early echinoderm taxa inform crinoid origin and arm evolution
}

\author{
Thomas E. Guensburg, ${ }^{1}$ (1) James Sprinkle, ${ }^{2}$ Rich Mooi, ${ }^{3}$ Bertrand Lefebvre, ${ }^{4}$ Bruno David, ${ }^{5,6}$ \\ Michel Roux, ${ }^{7}$ and Kraig Derstler ${ }^{8}$
}

${ }^{1}$ IRC, Field Museum, 1400 South Lake Shore Drive, Chicago, Illinois 60605, USA <tguensburg@ fieldmuseum.org>

${ }^{2}$ Department of Geological Sciences, Jackson School of Geosciences, University of Texas, 1 University Station C1100, Austin, Texas

78712-0254, USA <echino@jsg.utexas.edu>

${ }^{3}$ Department of Invertebrate Zoology, California Academy of Sciences, 55 Music Concourse Drive, San Francisco, California 94118, USA $<$ rmooi@calacademy.org>

${ }^{4}$ UMR 5276 LGLTPE, Université Claude Bernard, Lyon 1, France < bertrand.lefebvre@univ-lyon1.fr>

${ }^{5}$ Muséum National d'Histoire Naturelle, Paris, France < bruno.david@mnhn.fr>

${ }^{6}$ UMR CNRS 6282 Biogéosciences, Université de Bourgogne Franche-Comté, 21000 Dijon, France <bruno.david@ mnhn.fr>

${ }^{7}$ Muséum National d'Histoire Naturelle, UMR7205 ISYEB MNHN-CNRS-UMPC-EPHE, Département Systématique et Évolution, CP 51, 57 Rue Cuvier, 75231 Paris Cedex 05, France <mich.roux51@gmail.com>

${ }^{8}$ Department of Earth and Environmental Studies, University of New Orleans, 2000 Lake Shore Drive, New Orleans, Louisiana 70148, USA

$<$ kderstle@uno.edu>

\begin{abstract}
Intermediate morphologies of a new fossil crinoid shed light on the pathway by which crinoids acquired their distinctive arms. Apomorphies originating deep in echinoderm history among early nonblastozoan pentaradiate echinoderms distinguish Tremadocian (earliest Ordovician) crinoid arms from later taxa. The brachial series is separated from the ambulacra, part of the axial skeleton, by lateral plate fields. Cover plates are arrayed in two tiers, and floor plates expressed podial basins and pores. Later during the Early Ordovician, floor plates contacted and nestled into brachials, then were unexpressed as stereom elements entirely and cover plates were reduced to a single tier. Incorporation of these events into a parsimony analysis supports crinoid origin deep in echinoderm history separate from blastozoans (eocrinoids, 'cystoids'). Arm morphology is exceptionally well-preserved in the late Tremadocian to early Floian Athenacrinus broweri new genus new species. Character analysis supports a hypothesis that this taxon originated early within in the disparid clade. Athenacrinus n. gen. (in Athenacrinidae new family) is the earliest-known crinoid to express what is commonly referred to as 'compound' or 'biradial' morphology. This terminology is misleading in that no evidence for implied fusion or fission of radials exists, rather it is suggested that this condition arose through disproportionate growth.
\end{abstract}

UUID: http://zoobank.org/b383e039-3298-4472-a7e3-e81684f87cfe

\section{Introduction}

The origins of crinoids remain debated in disparate approaches (most recently Guensburg, 2012; Ausich et al., 2015a, b; Guensburg et al., 2016; Sheffield and Sumrall, 2019a, b). Bearing on this issue are the earliest-known (Tremadocian, 485.4477.7 Ma), crinoids, but the fossils are few and imperfect (Ubaghs, 1969; Guensburg and Sprinkle, 2003, 2009; Guensburg, 2012; Guensburg et al., 2016). Athenacrinus new genus, described here, adds clarity to our understanding of earliestknown crinoid arms. We use new morphologic data, together with those from other Tremadocian crinoids, to characterize this skeletal construction of arms and to compare similar anatomy outside the crinoid clade with that of more archaic echinoderms. This information invites a reanalysis of crinoid origin using a new phylogenetic dataset. Arm data from Tremadocian crinoids, combined with data from younger (Floian, late Early Ordovician) crinoids documents the events preceding the acquisition of typical Paleozoic crinoid morphology.

Athenacrinus $\mathrm{n}$. gen. is the earliest-known crinoid to express so-called 'biradial' morphology. This type of cup plating characterizes many disparid crinoids in which fixed ray plating consists of single elements in some rays, and two plates in others. A new explanation for the origin of this morphology is offered.

The known crinoid record begins during the middle Tremadocian (excepting the problematic middle Cambrian fossil Echmatocrinus Sprinkle, 1973). Oldest in this succession are the camerate-like protocrinoids Glenocrinus Guensburg and Sprinkle, 2003 and Titanocrinus Guensburg and Sprinkle, 2003, along with the cladid-like form Apektocrinus Guensburg and Sprinkle, 2009. Titanocrinus is joined up-section by the 
camerate-like Eknomocrinus Guensburg and Sprinkle, 2003 and the earliest disparid-like crinoid, Alphacrinus Guensburg, 2010. Aethocrinus Ubaghs, 1969 and the earliest Athenacrinus n. gen. occur just below the Floian boundary. A broad picture of Tremadocian crinoid evolution based on these occurrences is characterized by standardization and reduction that accompanied emergence of camerate, cladid, and disparid clades.

\section{Materials and methods}

Taphonomy and preparation.-Syntaxial overgrowths and dissolution weathering, along with abrasion, require consideration in the context of the finely detailed morphology described here. Taphonomic effects are patchy and vary within and among specimens. Etching corrodes plate surfaces, whereas evidence of syntaxial overgrowths cover and fill fine details in many places. Because of the importance of these effects in interpretation, detailed preservation information is found in the section Hypodigm, preservation and localities under Systematic paleontology.

An air scribe was used for rough preparation; specimens were finished by hand with fine needles, a slow method needed for the indurated matrices. The paratype USNM 165237 was previously prepared by air abrasion. Most images are multifocus montages prepared at the Field Museum with a Leica DMS 300 digital microscope and software. Large field montage images were prepared at the Illinois Natural History Survey, Urbana. Imaging included dry, water-immersed, and ammonium chloride-coated views under various lighting.

Terminology.-Basic terms including theca, floor, and cover plates, and interradials are used consistently as homologous across all of the early echinoderms discussed here. Crinoid terminology is that of Ubaghs (1978) with the following exceptions: (1) the cup base circlet, 'basals' according to the Treatise on Invertebrate Paleontology (Ubaghs, 1978), are here considered 'infrabasals' (Guensburg and Sprinkle, 2003), and (2) biradial terminology used for disparids is not accepted; instead radials are the first ray plates. Subsequent plates are designated fixed cup-like (wide, similar to radials) or free brachials, regardless of relative position (see section Disproportionate cup ray plating in disparid crinoids: 'Compound radials' and 'biradials,' below).

Two-tiered cover plating here refers to cover plates stacked in rows, as distinct non- or little-intercalated layers. Presumably these formed a continuous but slightly flexible sheet that was hinged at the contact with floor plates. This trait is not unique to crinoids, occurring elsewhere in certain edrioasterid edrioasteroids (e.g., Paredriophus Guensburg and Sprinkle, 1994, Pseudedriophus Sprinkle and Guensburg, 2015), more derived forms that retain axial anatomy similar to plesiomorphic nonblastozoan basal pentaradiates (e.g., Camptostroma Ruedemann, 1933, Stromatocystites Pompeckj, 1896, Kailidiscus Zhao et al., 2010). No standardized terminology exists for the two tiers of arm cover plating, and no terminology links cover plates of edrioasteroid-like basal pentaradiate echinoderms with those of early crinoids. 'Primary' was used for lateral, and 'secondary' for medial cover plates in previous work on the Cambrian basal pentaradiate Stromatocystites (Paul and Smith, 1984). 'Inner' and 'outer' were used by Brower (2006) for two-tiered Late Ordovician crinoids. The term 'lappets' was applied to camerate crinoids with a single biserial tier (Kolata, 1982) and, in some cases, to extant crinoid cover plates (Clark and Clark, 1915). 'Lateral' and 'medial,' implemented here, apply to early crinoids and to cover plates of edrioasteroids and edriosteroid-like early taxa. Lateral cover plates can be considered homologous to 'primary' elements, and medial cover plates in part homologous to any other cover plate elements that occur more medially.

Plates separating the axial complex from free brachials occur in the early cladid-like Apektocrinus and Aethocrinus, as well as the protocrinoid Titanocrinus. Here, these are called 'extraxial lateral plates.' It is critical to recognize that these are not cover plates, which can be superficially similar. Extraxial laterals lie aboral to the floor plates, interradial elements extended from and contiguous with the tegmen field. Lateral cover plates are of axial origin and lie adoral to floor plates, extraxial laterals are aboral, being extended interradial elements. Similar plates are found in living crinoids, in which they are termed 'laterals' (Roux and Lambert, 2011, and others), but have also been referred to as 'adambulacrals' (Breimer, 1978). The latter term is not preferred because it has long been used in extant forms such as asteroids for elements that are most likely not homologous (Mooi and David, 2000). These can be irregular plate fields, exemplified by the stalked Gephyrocrinus messingi (Roux and Lambert, 2011, fig. 3), or organized in a single row, exemplified by the comatulid Pachylometra inequalis (Clark and Clark, 1915, pl. 27, fig. 1168). These latter series superficially resemble lateral cover plates, but are, in fact, extraxial laterals.

Terminology for blastozoans follows Parsley (1982; Eumorphocystis Branson and Peck, 1940), Paul (1968; Macrocystella Callaway, 1877), Ubaghs (1968; Rhopalocystis Ubaghs, 1963), and Sprinkle (1973; Cambrian eocrinoids), except that we make the distinction that all extraxial morphology is treated as nonhomologous with crinoids, including terms such as 'basals' and 'radials' that have been used interchangeably (see Guensburg and Sprinkle, 2007). Distinctions to this effect are created in the character list used in the phylogenetic analysis (see section Independent origins of crinoids and blastozoans among early radiate echinoderms, below).

Repositories and institutional abbreviations.-Athenacrinus broweri n. gen. n. sp. specimens are deposited in the Field Museum of Natural History (PE), Chicago, Illinois, and the National Museum of Natural History (formerly United States National Museum, USNM), Washington, DC. Figured specimens of other taxa are housed in the Field Museum; Museum of Comparative Zoology (MCZ), Harvard University, Cambridge, Massachusetts; Muséum National d'Histoire Naturelle (MNHN) Paris; Paleontology Repository, Sam Noble Museum (OU), University of Oklahoma, Norman; University of Illinois (UI X), Urbana; University of Iowa (SUI), Iowa City; Non-vertebrate Paleontology Laboratory (\#\#\#\#TX\#\#\#, NPL), University of Texas, Austin; and Yale Peabody Museum (YPM), New Haven, Connecticut. 


\section{Systematic paleontology}

\author{
Class Crinoidea Miller, 1821 \\ Subclass Disparida Moore and Laudon, 1943 \\ Family Athenacrinidae new family
}

Diagnosis.-Disparids with wide pentameric stalk expanding and without inflection at cup transition; wide CD interray; $\mathrm{C}$ and $\mathrm{E}$ ray with primibrachial one inserted down into the cup as compared to A, B, and D rays; CD plate field to left of anal series arising from anibrachial; arms with floor plates and two-tiered cover plating.

\section{Genus Athenacrinus new genus}

Type species.-Athenacrinus broweri new species.

Diagnosis._-As for the type species, by monotypy.

Etymology.-Compounding of Athena, patron goddess of classical Athens, whose often lithe and rangy representation is reminiscent of this elegant taxon, and crinus, the standard suffix applied to crinoid taxa.

Remarks.—See remarks for Athenacrinus broweri n. gen. n. sp.

\section{Athenacrinus broweri new species}

Figures 1-6, 7.3, 8.4

1970 Hybocrinus sp. A Lane, p. 9, 10, 12, pl. 1, fig. 8, text-fig. 2E.

Type specimens.-Holotype PE 52742; paratypes PE 5275052753 and USNM 165237.

Diagnosis.-Disparid with cup-like primibrachial 1 in $\mathrm{C}$ and $\mathrm{E}$ rays; four fixed primibrachials in $\mathrm{E}$; wide multiplated $\mathrm{CD}$ interradius; anitaxial column arising from primibrachial 1, 2, or both 1 and 2; arms long, branching isotomously several times; two-tiered cover plating with medial cover plates arranged in alternating double biseries; stalk pentameric to cup, wide, expanding into cup without inflection.

Occurrence.-The six Athenacrinus broweri n. gen. n. sp. type specimens were collected from the Slope-forming shaly siltstone member, Hintzeia celsaora trilobite horizon (G1 of Hintze, 1973), Fillmore Formation, central Black Hills, The Barn Quadrangle, Township 22 South, Range 13 West, Millard County, Utah. This geographic location includes the middle portion of what has become known as the Ibex Area (Taylor and Miller, 1989). Approximately the lower three-quarters of the Slope-forming shaly siltstone member (Hintze, 1973) are considered upper Tremadocian in age, whereas the upper remaining quarter above ranges into the lower Floian. This part of the section is less resistant to weathering and therefore less well exposed, with the most complete exposure near the measured Mesa and C-sections of Hintze (1973). In all but one case, finds were projected laterally to these marked sections to obtain close stratigraphic control. The stratigraphic position of paratype PE 52751 is estimated based on lithofacies associations and nearby exposure.

Five specimens occurred as isolated finds, without other echinoderms. Paratype PE 52752 occurs with a few dismembered stalk and arm fragments of an apparent iocrinid. Lack of morphologic overlap suggests only a single individual. The Athenacrinus broweri $\mathrm{n}$. gen. $\mathrm{n}$. sp. fragments represent individuals larger than the iocrinid, $\mathrm{C}$ and $\mathrm{E}$ with 'biradials,' the stalk much wider, distal stalk with scar pits, brachials U-shaped in cross section, and the arms longer with more brachials between branchings.

Specific data are as follows: (1) holotype PE 52742, small slightly compressed calyx in lateral view with projecting anal sac, B-E exposed, with uncrushed proximal stalk, and thin syntaxial overgrowths, embedded within the upper surface of an intraformational conglomerate, upper Tremadocian, $\sim 215 \mathrm{~m}$ above the base of the Fillmore Formation, NW SW NW section 20, collected by Guensburg in 1991; (2) paratype PE 52750, a large flattened partial cup with proximal stalk with $\mathrm{E}$, one B primibrachials, part of anal sac, A, B, E exposed, much weathered and fractured, lower Floian, on intraformational conglomerate, $238 \mathrm{~m}$ above the Fillmore base, and $\sim 2 \mathrm{~m}$ below Calathiumbearing bioherm (Church's Reef), SW NE SE section 7, collected by Sprinkle in 1989; (3) paratype PE 52751, slightly compressed well-preserved intermediate-sized partial crown and etched proximal stalk and separate distal stalk segment, cup disarticulated, arm transitioning to partial tegmen, upper Tremadocian, in lime mudstone, estimated middle third of the Slope-forming shaly siltstone member of the Fillmore, NW SW NE section 17, collected by Guensburg in 1992; (4) paratype PE 52752, articulated arm and stalk segments in intraformational conglomerate, etched with partial syntaxial overgrowths, floor plates well-exposed in one area, lower Floian, $1 \mathrm{~m}$ below Calathium-bearing bioherm (Church's reef), $240 \mathrm{~m}$ above the base of the Fillmore, SE SE SE section 7, collected by David and Jim Sprinkle in 1991; (5) paratype USNM 165237, crushed cup with lower arm bases and anitaxis, and small segment of crushed stalk, C-D exposed, upper Tremadocian or lower Floian, packstone, exact horizon unavailable, although accompanying notes indicate trilobite zone G1, section 19 or 20 along C-section, collected by Lehi Hintze and students, 1970s; (6) paratype PE 52753, a well-preserved long stalk segment in two pieces, partial cup collapsed, in lime mudstone, upper Tremadocian, $219.5 \mathrm{~m}$ above the Fillmore base, SW SW NW section 20, collected by Guensburg in 1992.

Description.-Estimated maximum complete length $>25 \mathrm{~cm}$; estimated maximum crown height at least $12 \mathrm{~cm}$; cup steep-sided, zigzag juncture with stalk below, oblong pentalobate in cross section at level of primibrachial one, with protruding $\mathrm{E}$ ray, $\mathrm{D}$ and $\mathrm{E}$ rays shifted to accommodate wide CD interradius; cup expansion in continuity with proximal stalk, continuing upward onto free arms, taller than wide in small holotype, wider than tall in large paratype PE 52750, shallow indentations at infrabasal-radial triple junctures in large paratype PE 52750, plate surface smooth; infrabasals (basals according to Ubaghs, 1978) five, large, approximately as high as wide in small holotype, wider than tall in large paratype PE 52750, hexagonal in holotype to rounded 


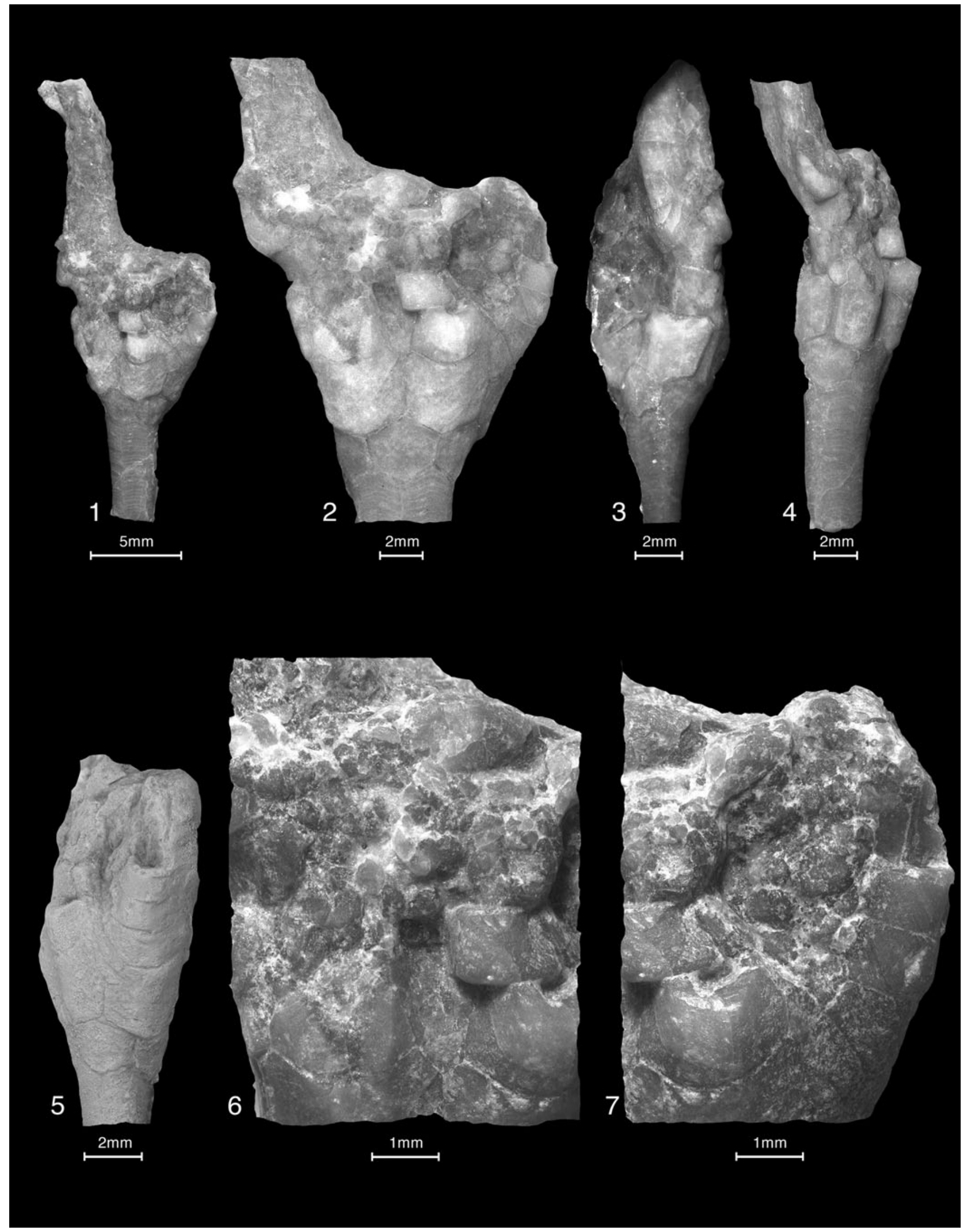

Figure 1. Athenacrinus broweri $\mathrm{n}$. gen. n. sp., holotype PE 52742, small calyx with short anal sac and proximal stalk: (1) entire, immersed; (2-5) AB, C, A, and E views, respectively, all immersed except coated $\mathrm{E}$ view, E radial proportionately shorter than other radials; $(\mathbf{6}, 7) \mathrm{AB}$ and $\mathrm{AE}$ interrays and tegmen, several small cover plates extending over peristome area, small rounded plates filling tegmen interrays, dry uncoated images. 


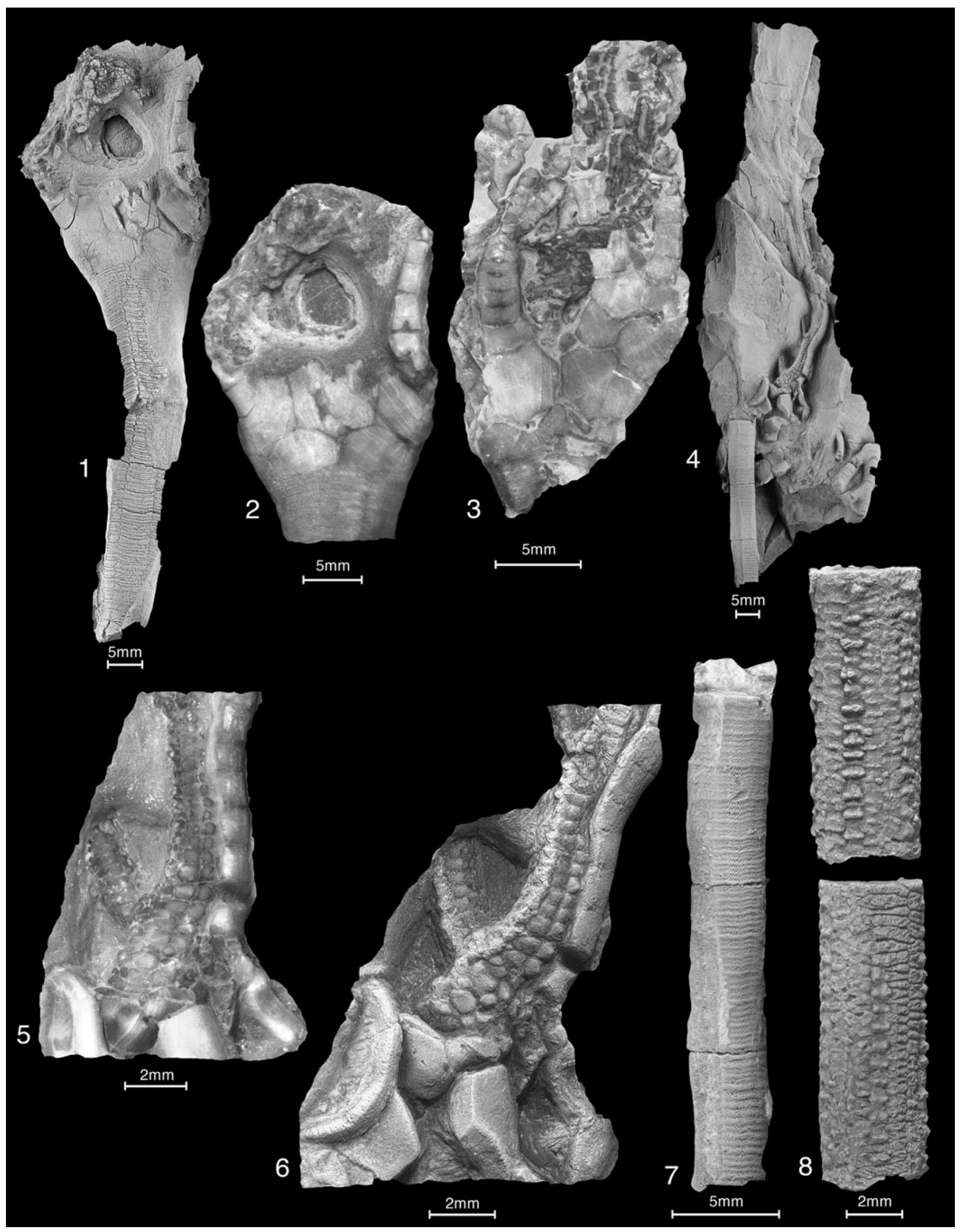


Figure 2. Athenacrinus broweri $\mathrm{n}$. gen. n. sp.: (1, 2) paratype PE 52750, large cup showing rays A, B, and E with proximal stalk: (1) entire specimen, coated; (2) cup and stalk, proximal two meres not reaching laterally adjacent meres, four primibrachials above short E radial, immersed; (3) paratype USNM 165237, flattened cup with short stalk segment, CD view, irregular posterior plating, small gaps between adjacent primibrachials accentuated by air abrasion, immersed; (4-8) paratype PE 52751, disarticulated cup with articulated arm, arm segments, and stalk: (4) entire specimen, coated; (5) disarticulated cup, cover plating showing tegmen to arm transition, immersed; (6) similar view with cup plates and proximal stalk pentamere ring in cross section (left) showing large round lumen and fine crenulae; (7) proximal stalk, slightly weathered showing marginal crenulae, coated; (8) two views of separate medial-distal stalk segment, above with short projections centered on pentameres, accessory ossicular covering, below weathered on right showing pentameres beneath ossicular layer, coated.

subhexagonal in paratype PE 52750; radials are largest cup plates, in lateral contact all around, with slightly diverging sides, broad rounded plate midlines extending upward to primibrachial 1, plates flattening laterally forming shallow indentations interradially, deeply concave, declivate facets in A-D, slightly concave facet in E; A radial irregular octagonal in holotype, in contact with two interradials in EA interradius, and one interrradial in $\mathrm{AB}$; $\mathrm{B}$ radial irregular heptagonal, articulating with one interradial each in $\mathrm{AB}$ and $\mathrm{BC}$ interrays; C radial (inferradial of Ubaghs, 1978) heptagonal, in contact with one interradial each in $\mathrm{BC}$ and $\mathrm{CD}, \mathrm{D}$ radial apparently heptagonal, contacting one interradial each in $\mathrm{CD}$ and $\mathrm{DE}$ with radial facet offset to left away from $\mathrm{CD}, \mathrm{E}$ radial not fully exposed, about as wide as tall, perhaps irregular heptagonal, articulating with one large nearly trapezoidal interradial in EA, perhaps one interradial in DE, positioned deep in cup, rising to $\sim 60 \%$ of adjacent $\mathrm{A}$ radial; primibrachials smaller than radials, tapering, transitional to free brachials, A, B, D primibrachials 1 , perhaps 2 , fixed, bordering small interradial fields, A ray primibrachial 1 articulating with two fixed interradials each in $\mathrm{AB}$ and $\mathrm{EA}, \mathrm{C}$ primibrachial 1 ('superradial') cup-like, fixed, large, nearly rectangular, wider than tall, bordering wide field of small CD plates and at least two BC interradials, primibrachial 2 in C-ray is an anibrachial, approximately as tall as wide but narrower than primibrachial 1, E primibrachials unlike other rays, one ('superradial') cup-like, large, octagonal, nearly as wide as radial below, inset downward into the cup; E primibrachials unlike other rays, at least four primibrachials fixed-primibrachial 1 hexagonal, nearly as wide as radial, much wider than tall, extending partly above adjacent (A and D) radials, articulating with radial below along short concave suture, and longer concave suture above, primibrachial 2 apparently in contact with two interradials each in EA and DE, primibrachial 3 much narrower than primibrachial 2, primibrachial 4 narrower still; interradials of the anterior interrays in small, narrow, depressed fields, arranged in 1-2-? pattern, AB and BC, large nearly trapezoidal ?fixed interradial in EA of holotype articulating with left shoulder of D radial, lower left shoulder of $\mathrm{D}$ primibrachial 1, a long suture along the right side of $\mathrm{A}$, and a short suture with EA interradial above; posterior interray/anitaxis wide, raised column a low rounded ridge arising from left margin of primibrachial one, two, or both, extending upward to narrow anal sac, a wide field of small depressed plates forming pavement to left of anitaxis; posterior interray of paratype USNM 165237 irregular with two large plates expressed as cup plates contacting $\mathrm{C}$ radial, left-hand plate supporting first anitaxis column plate, right plate represented by wide primibrachial 1 with irregular primibrachials above ray trunk of paratype PE 52751 irregular; tegmen convex, reaching level of $\mathrm{E}$ primibrachial four in holotype, narrow tapering anal sac projecting from CD slightly more than cup height, dorsal anal sac formed by anitaxis column, ventral surface with small thin, smooth platelets; ambulacra extending onto tegmen, cover plates exposed on paratype PE 52751 becoming larger and heavier on tegmen, near summit, in holotype and paratype PE 52751 with a large disc-shaped plate (?madreporite) near summit on paratype PE 52751, interradial (interambulacral) areas with many small rounded loosely fitted irregular platelets of varying sizes, apparent granular dermal ossicles in interstices between platelets; arms incomplete, partial information suggesting variation; arms thin, many times longer than cup height, initial branch isotomous with seven tapering primibrachials in D ray of paratype USNM 165237, at least four or five branches distally in paratype PE 52751, fewer in extremely long arm segment of PE 52752, apparently isotomous; arm trunk of paratype PE 52751 with irregular plated mosaic (no uniserial series) and initial arm branch arising from near the cup-free arm juncture; mid- and distal arms then very gradually tapering to tips, brachials variable, wider than high to nearly equal height to width proximally, higher than wide distally, brachials with deep, wide, ambulacral coelomic channel, bottom of coelomic channel with secondary groove, floor plates much wider than tall, nestled into ambulacral channel, lateral rectangular exposed surfaces vary from almost no exposure to well-exposed rectangular surfaces, three or four floor plates per brachial, each podial basin expressed as abradial wedge-shaped notch at boundary between successive elements, interior space between floor plates above and brachials below large irregular and trilobate; cover plates arranged in outer lateral and inner medial stacked series, lateral series large, rectangular, in one-to-one correspondence with lateral floor plate extensions, medial elements small, interdigitating across the perradial suture, themselves arranged in a loose double alternating biseries with smaller elements at junctures of adjacent lateral elements, larger elements situated near the center of each lateral cover plate below; stalk widest at cup juncture, then tapering distally nearly to holdfast, pentameric throughout except in distalmost region where stalk becomes a plate mosaic, proximalmost meres small chevron-shaped wedges forming triple juncture with adjacent basals, subjacent two or three meres expanding laterally, pentamere four or five attaining lateral contact with adjacent meres, proximal region meres laterally offset to nearly aligned, very thin, wafer-like, distal pentameres, thicker, interlocking across lateral sutures, distal region polymeric with many irregular meres in ranks; medial stalk in paratype PE 52751 with outer covering of small dermal plates aligned with meres below, centers of meres with projecting larger flattened knob-like elements, each of these inserted into a pit in subjacent mere. 


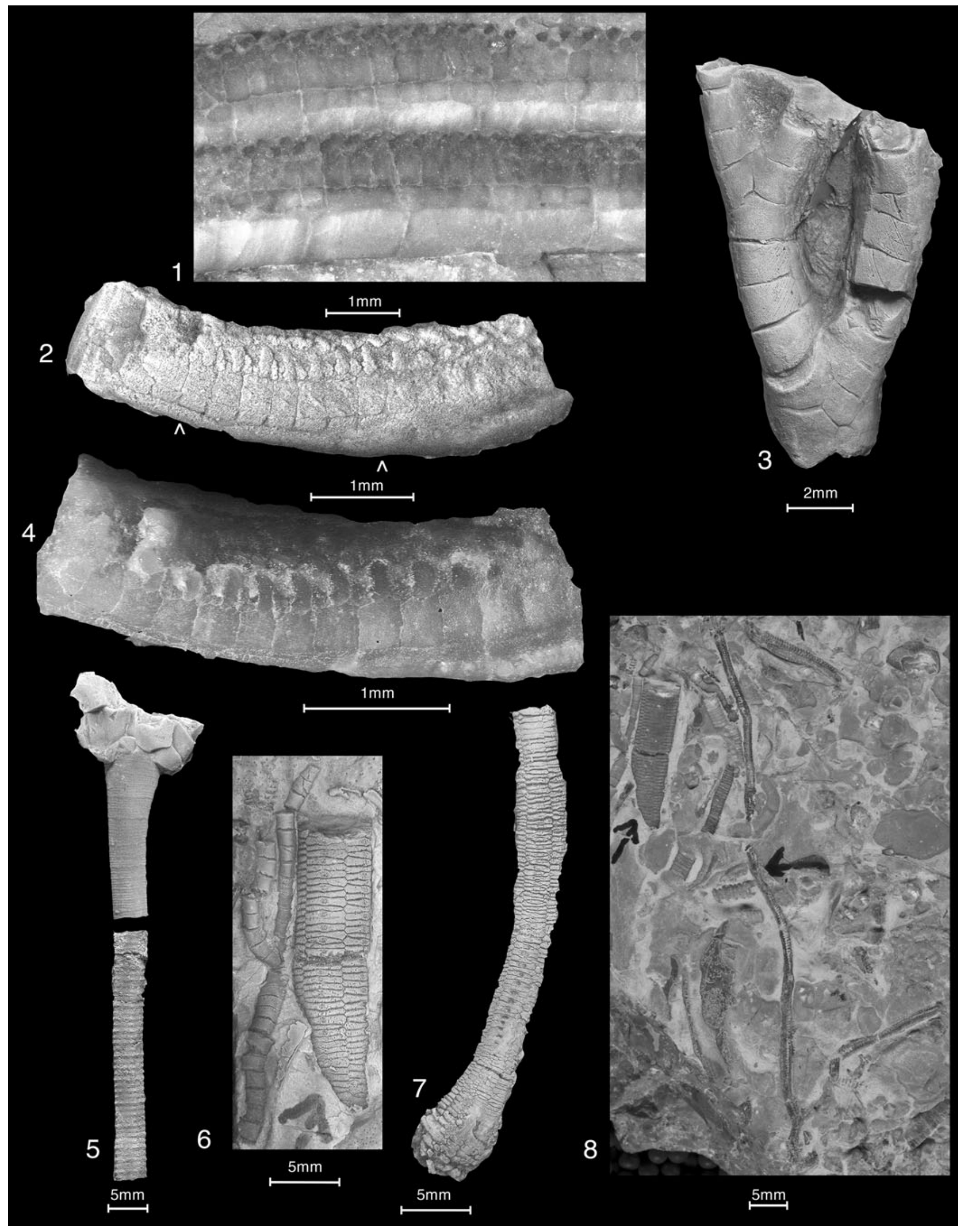


Figure 3. Athenacrinus broweri $\mathrm{n}$. gen. n. sp.: (1-4) paratype PE 52751 (continued from Fig. 2.1-2.4): (1) adjacent ramules or armlets, midarm, medial cover plates in regular alternating double biseries, immersed; $(\mathbf{2}, \mathbf{4})$ well-preserved arm segment: (2) brachials just visible at bottom, then floor plates (small rectangular elements), large rectangular lateral cover plates, and alternating double or triple series along perradial suture above, coated; (4) specimen turned to accentuate cover plates, dry, raking light; (3) arm trunk with two branchings, irregular plating below; (5) paratype PE 52753, well-preserved collapsed proximal cup, BC view, anibrachial apparently primibrachial one, attached proximal stalk segment and detached medial stalk with small, $\sim 1 \mathrm{~cm}$ missing interval, pentameres with spinose processes, coated; (6-8) paratype PE 52752, associated arm and stalk segments: (6) medial stalk and adjacent arm segment, meres with attachment pits, coated; (7) distal stalk transitioning below to plate mosaic, coated; (8) much of surface with specimen segments showing articulated long arm segment with two branchings below, then long section without branchings, dry uncoated.

Etymology.-The species name honors the late James C. Brower, student of fossil crinoids, who revealed much about early crinoids in his long and productive career. His pioneering study of feeding strategies among Late Ordovician crinoids included cover plate information incorporated into this study.

Paleoenvironmental context.-Paleogeographic reconstructions model an equatorial passive shelf context for the Fillmore Formation (Blakey, 2019). Dattilo (1993) published a detailed sedimentologic study of the Slope-forming shaly siltstone member. Church (1974) analyzed the Calathium-rich bioherm in the upper portion of this interval of the Fillmore. These studies indicate that Athenacrinus broweri n. gen. n. sp. inhabited shallow, open-marine, carbonate-dominated settings at or above storm wave base. Recently, evidence has been presented that the occurrence of these earliest crinoids occurred during an early phase of the Great Ordovician Biodiversification Event (GOBE), when oceanic oxygenation was beginning to increase, particularly in shallow-water settings (Edwards, 2019).

Four specimens occurred atop surfaces of storm-generated, flat-pebble conglomerates; two specimens were embedded in intervening lime muds and silts. Specimens are not whole, instead preserved as incomplete but articulated partial skeletons. No specimen remains attached by a holdfast, but nearby lithified, storm-generated, flat-pebble conglomerate beds and sponge-algal mounds occasionally hosted crinoids and blastozoans, based on distinctive holdfasts.

Remarks. - Even the small sample size is sufficient to indicate considerable intraspecific variation in Athenacrinus broweri n. gen. n. sp. Variable arm and cup construction have been reported in other disparids including Cincinnaticrinus Warn and Strimple, 1977, Anomalocrinus Meek and Worthen, 1865 (Moore, 1978), and Ristnacrinus Öpik, 1934 (Ausich and Rozhnov, 2017). The two-tiered cover plate pattern of Athenacrinus broweri n. gen. n. sp. continues onto the tegmen where it transitions into a single-tiered double biseries (Figs. $2.5,2.6,6)$. This thecal cover plate pattern is common among pentaradiate echinoderms (i.e., certain blastozoans, crinoids, edrioasteroids). The question as to whether a two-tiered earliest crinoid arm cover plate pattern is a class-level apomorphy is problematic given that no immediate crinoid ancestor is known. The distal stalk of paratype PE 52751 is covered with secondary ossicles. This expression is documented elsewhere only in Musivocrinus Termier and Termier, 1949 from the Permian of Timor (Termier and Termier, 1949) to our knowledge, and its phylogenetic significance is unknown.
Three characters provide collective evidence that indicates that Athenacrinus n. gen. is an early disparid by traditional practice: (1) an anibrachial plate and subsequent uniserial anal column arising from the $\mathrm{C}$ ray, (2) a monocyclic cup extending only a short distance above radials, and (3) disproportionate ray plating in $\mathrm{C}$ and $\mathrm{E}$ rays. This third feature characterizes a diversity of disparids including anomalocrinids, cincinnaticrinids, and othneiocrinids. Othneiocrinus Lane, 1970 (substitute for Atopocrinus Lane, 1970) is closest to Athenacrinus n. gen. in terms of age, geographic occurrence, and morphology. Similarities include the wide, expanding cup, wide stalk with proximal pentameres, and the fact that the third $\mathrm{C}$ ray plate, primibrachial two, is the anibrachial (according to Ubaghs, 1978). This last trait is an uncommon expression, known elsewhere only in the Late Ordovician Peniculocrinus Moore, 1962, a eustenocrinid cup the plating of which is otherwise unlike Athenacrinus n. gen. in lacking interradials and with radials (first ray plates) equal in width to the first primibrachials above (Moore, 1962). Othneiocrinus expresses much shorter primibrachials, larger first cup-like primibrachials, and small armlets, in contrast to the more robust branches of Athenacrinus n. gen.

Alphacrinus, Tremadocian to Floian from the Ibex area, differs from Athenacrinus n. gen. in expressing: (1) a cup-like primibrachial one only in $\mathrm{C}$ where it is the anibrachial, (2) heavy stellate ornament, (3) endotomous armlets, (4) an elongate anal sac extending beyond the arm tips, and 5) a narrower stalk with more closely spaced nodals. Together, the two Tremadocian taxa show that disparid diversification occurred soon after the origin of the crinoid clade.

\section{Origin of the crinoid arm}

Crinoid arms are not derived from blastozoan feeding appendages. - Crinoid and blastozoan feeding appendages are constructed in fundamentally distinct ways, with significantly different topologic relationships among only partly homologous body walls and body cavity systems (Ubaghs, 1953, 1978; Sprinkle, 1973; Mooi and David, 1998; Guensburg and Sprinkle, 2007; Guensburg et al., 2016). The character list and coding reflect these distinctions, which have not yet been fully implemented in a phylogenetic analysis. This interpretation is further supported by character evidence provided in this study. Briefly, blastozoan and crinoid arms express ambulacral floor and cover plates; no one has challenged the homology of these plate systems, and these are found in other major groups of echinoderms as well. Floor plates in blastozoans can form exposed primary appendage and brachiole structures. However, in crinoids, floor plates are thin, largely internal structures that the most crownward 


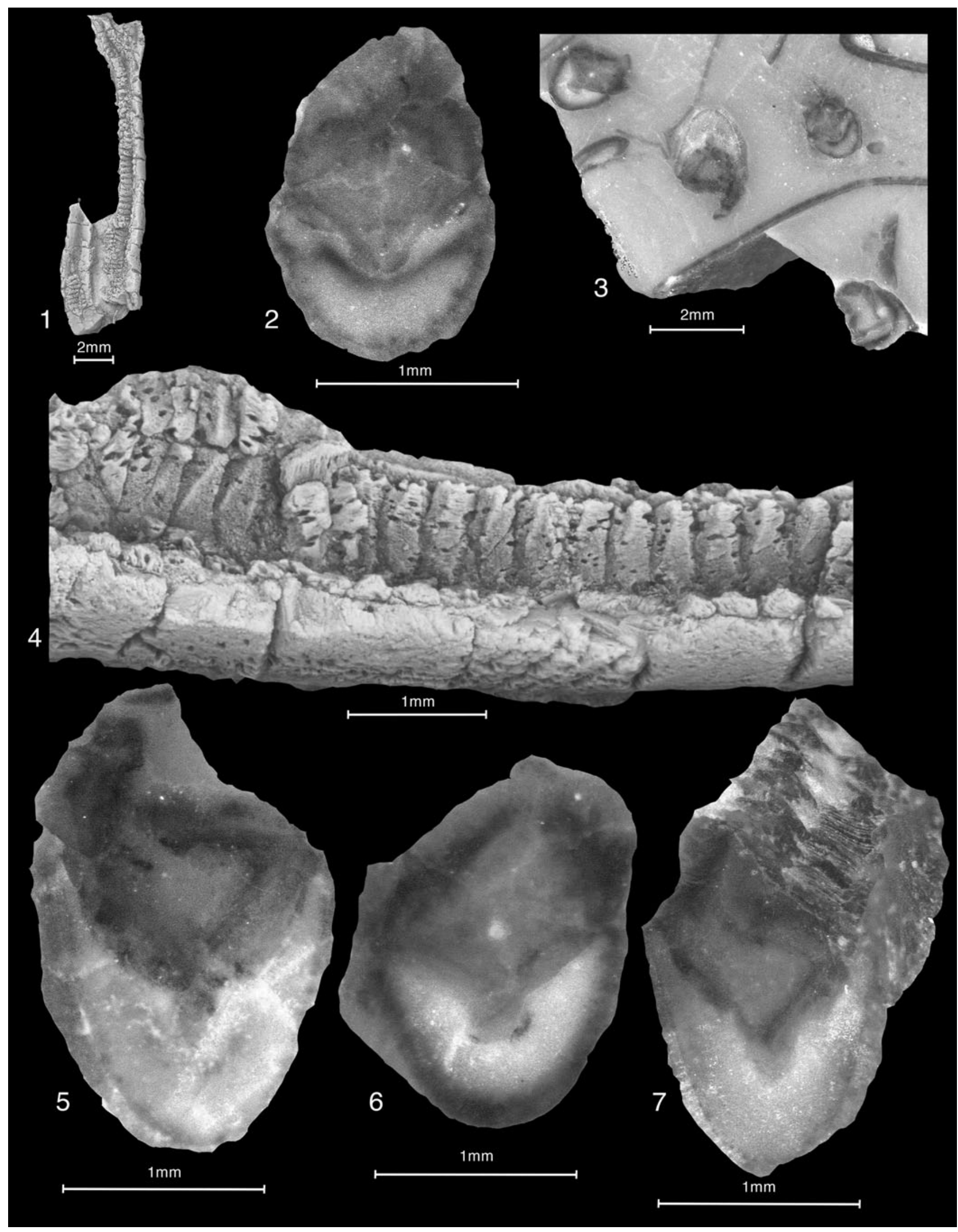


Figure 4. Athenacrinus broweri $\mathrm{n}$. gen. $\mathrm{n}$. sp., paratype PE 52752: $(\mathbf{1 , 4})$ two proximal arm segments: (1) entire, coated; (4) detail of best preserved lower right-hand portion, floor plates nestled into brachials, above series face on, below edge on, wedge-shaped podial basins, best preserved on left with faint rims and slotted articulating cover plates, three sequential small podial pores on right, coated, compare Figure 11.5 and 11.6, similar two-tiered cover plating and wedge-shaped podial basins; $(2,3,5-7)$ polished surfaces of medial to distal arm cross sections at or near right angles to arm axes, with syntaxial overgrowths, hints of dark organic matter, immersed: (2) distal arm, floor plates in near original position; (3) overview of associated cross sections depicted at lower magnification, current oriented segments; (5-7) three medial arm cross sections, much enlarged, subsidiary groove at bottom of adoral groove, floor plates collapsed or disarticulated: (6) an ?axillary with dual subsidiary groove.

crinoids do not express at all as stereom; these are instead represented by the tissue shelf that lies adoral to the extensions of the right and left somatocoels, but still supports the water vascular system (Nichols, 1960, figs. 4, 5; Mooi et al., 2005). Crinoid appendages extend from the ambulacral rays on the tegmen, and are supported by brachials derived from the extraxial thecal wall. Crinoid appendages always house extensions of the left and right somatocoels entering the arm at the thecal shoulders, emanating from these coeloms from within the theca. Blastozoan appendages lack these thecal openings and therefore also lack left and right somatocoel components, although presumably they were present as coeloms within the theca.

It has recently been proposed that a Late Ordovician blastozoan, Eumorphocystis multiporata Branson and Peck, 1940, constitutes a plesiomorphic sister group to crinoids (Sheffield and Sumrall, 2019a). A more complete response to this claim will be published elsewhere, but its relevance to the present work and the phylogenetic analysis require that a summary response be provided here. The putative sister-group claim is predicated on the observation that this taxon expresses arm cavities interpreted to have housed coeloms (left and right somatocoels). Therefore, the triserial arms of Eumorphocystis are assumed to be homologous with those of certain early crinoids (e.g., Athenacrinus n. gen, n. sp.). However, observation of 10 Eumorphocystis specimens other than the single example used in Sheffield and Sumrall (2019a) to hypothesize the existence of this homology indicates that these similarities are superficial. Most important among this evidence is that the specimen studied by Sheffield and Sumrall (2019a) provides incomplete information regarding putative coeloms. As preserved, the arms of this specimen do not reveal a situation in which these longitudinal appendage cavities are contiguous with the thecal cavity. Other specimens that we examined have appendages broken at their bases and preserve all of the elements necessary for an accurate portrayal of this relationship. These show that the large arm cavities of Eumorphocystis are confined to feeding appendages. These taper to form small pores in thecal floor plates that do not extend through the shoulder wall (Fig. 9). The function of such arm lumens is unclear. Earliest crinoids express large cavities that taper along the arms outward from the theca, with lateral plate fields separating the brachials from the floor plates (Guensburg and Sprinkle, 2003, pl 1.4; Guensburg and Sprinkle, 2009, figs. 1.2, 5.3; Fig. 10.1). It is this continuity, in conjunction with known patterns of early development in modern crinoids, which indicates the existence of left and right coelomic extensions throughout not only the full length of the arms, but also the pinnules as well (summarized by Hyman, 1955; Heinzeller and Welsch, 1994; and others). Eumorphocystis expresses biserial cover plating unlike the two-tiered patterns documented for earliest crinoids here. Every other trait of this taxon's skeleton indicates that it is a derived blastozoan, some anatomy of which is homoplastic with crinoids (see Parsley, 1982, for a similar interpretation).
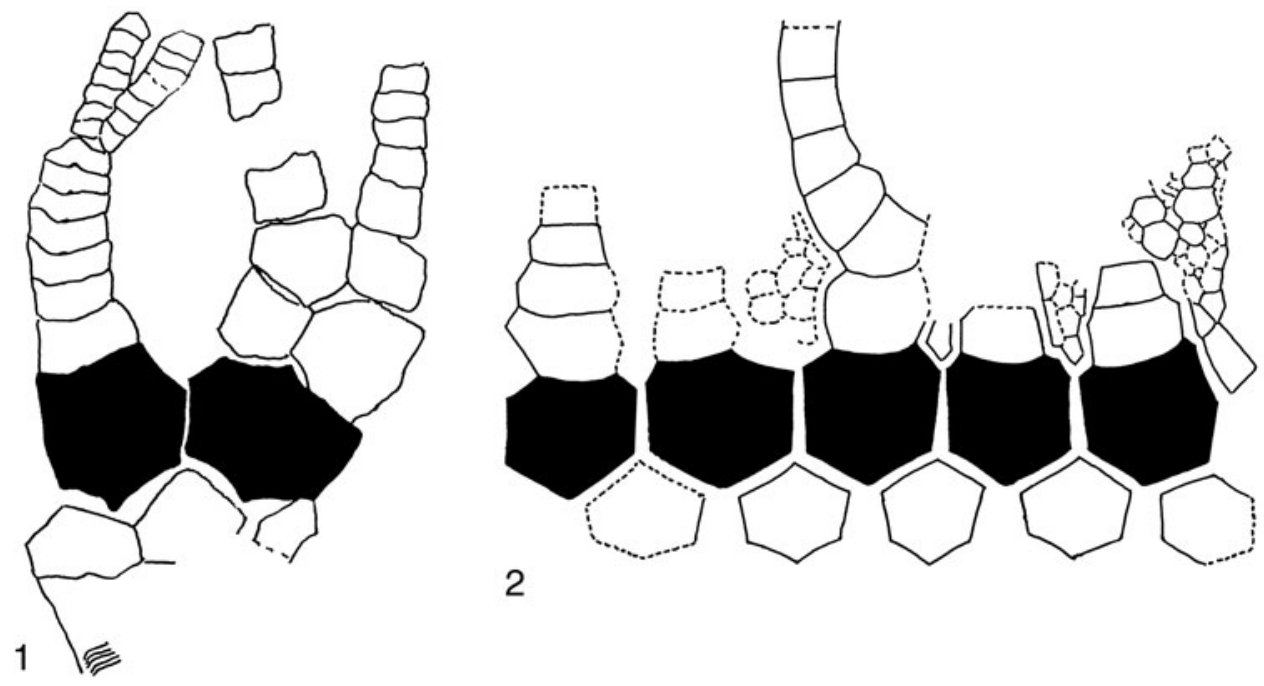

2

Figure 5. Athenacrinus broweri $\mathrm{n}$. gen. n. sp., line drawings with radials in black: (1) paratype USNM 165237, plate tracing, CD view, irregular posterior plating, much enlarged; (2) cup plate layout, A on right, based largely on holotype PE 52742, D fixed primibrachials provided from USNM 165237, C and E ray primibrachials one cup-like, disproportionately larger than those of other rays, AE interradials extending upward to level of primibrachials three or four, A, B and D rays with unknown number of fixed primibrachials, much enlarged. 


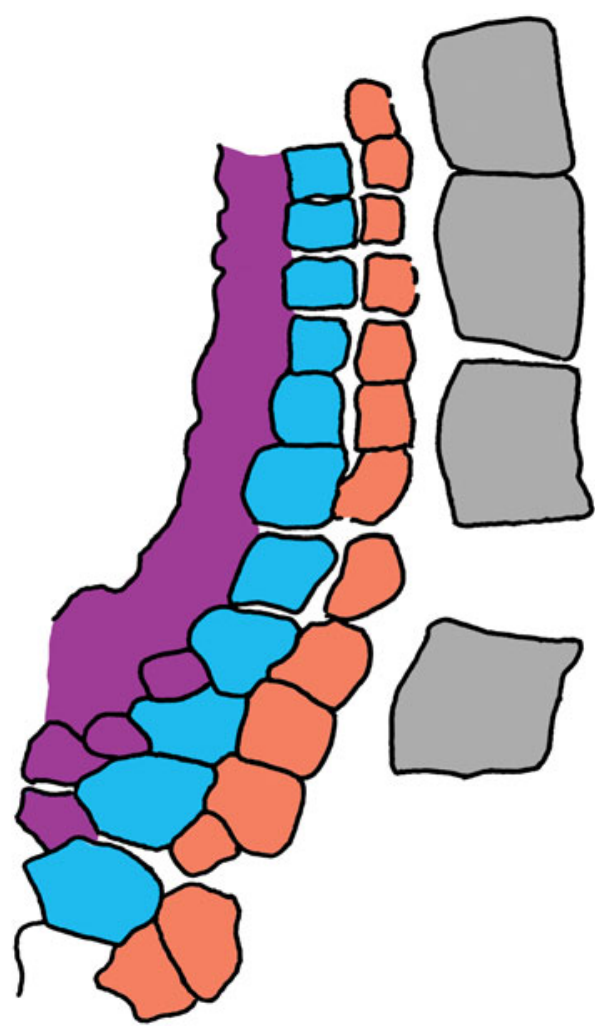

Figure 6. Athenacrinus broweri n. gen. n. sp., paratype PE 52751, arm-to-tegmen transition, traced, arm medial elements not well-exposed, partly covered, not individually depicted; compare Figure 2.5 and 2.6. blue = lateral cover plates (axial); gray $=$ brachials (extraxial); green $=$ laterals, not present here $($ extraxial $)$; orange $=$ floor plates $($ axial $)$; purple $=$ medial cover plates $($ axial $)$.

The earliest crinoid arms.-This discussion centers on recognition of a morphology characterizing the earliest crinoid arms from the middle Tremadocian (Figs. 2-4, 10, 11). As discussed above, modern crinoid anatomy reveals that arms are composite constructs-part axial, part extraxial (David et al., 2000; Mooi et al., 2005). Tremadocian crinoid skeletal anatomy reflects this duality even more than later taxa and begins to bring into focus the range of morphology present at that time. Data for their arm interiors are incomplete, but reasonably well-known for at least one taxon across the range of high-ranking taxa present at that time-disparid-like, cladid-like, and the camerate-like forms.

The ambulacral parts of the axial skeleton of earliest crinoids can be traced to the early Cambrian Camptostroma, an archaic edrioasteroid-like form with stubby arm-like structures (Durham, 1966, text-fig. 1; Derstler et al., 2018). A distinctive sequence orthogonal to the plane of the ray includes the podial basin and pore-bearing floor plates, and cover plates in rows diminishing in size as they meet from either side of the ambulacrum over the perradial suture. Initially in Camptostroma, these plate series are not as standardized or geometrically consistent, but the sequence is the same. This basic pattern occurs not only in the earliest, middle Tremadocian, crinoids (Guensburg and Sprinkle, 2003, 2009; Figs. 3.1, 3.2, 3.4, 4.2, 4.4-4.7, 10, $11.3,11.4$ ), but also edrioasterid edrioasteroids (Sprinkle and Sumrall, 2015) (e.g., compare Figs. 3.2, 3.4, 4.2, and 4.4-4.7 with Figs. 11.5 and 11.6) and the edrioblastoid Cambroblastus Smith and Jell, 1990 (Zhu et al., 2014).

Cover plates. - Earliest crinoid cover plates occur in two tierslateral and medial. It is important to recognize that two tiers refers to discrete layers or stories of cover plates, not a multiseries sequence within a single tier. Lateral cover plates are squared elements, whereas medials are lath- or wedge-shaped elements arranged in an alternating double biseries pattern. Relative sizes vary by taxon. The medial cover plates of Titanocrinus and apparently Eknomocrinus are larger than lateral cover plates (Figs. 7.2, 8.2, 10.3, 10.5, 10.6, 11.1), whereas lateral cover plates are larger than medials in Aethocrinus, Apektocrinus, Athenacrinus n. gen., and Alphacrinus (Figs. 3.1, 3.2, 3.4, 4.2,
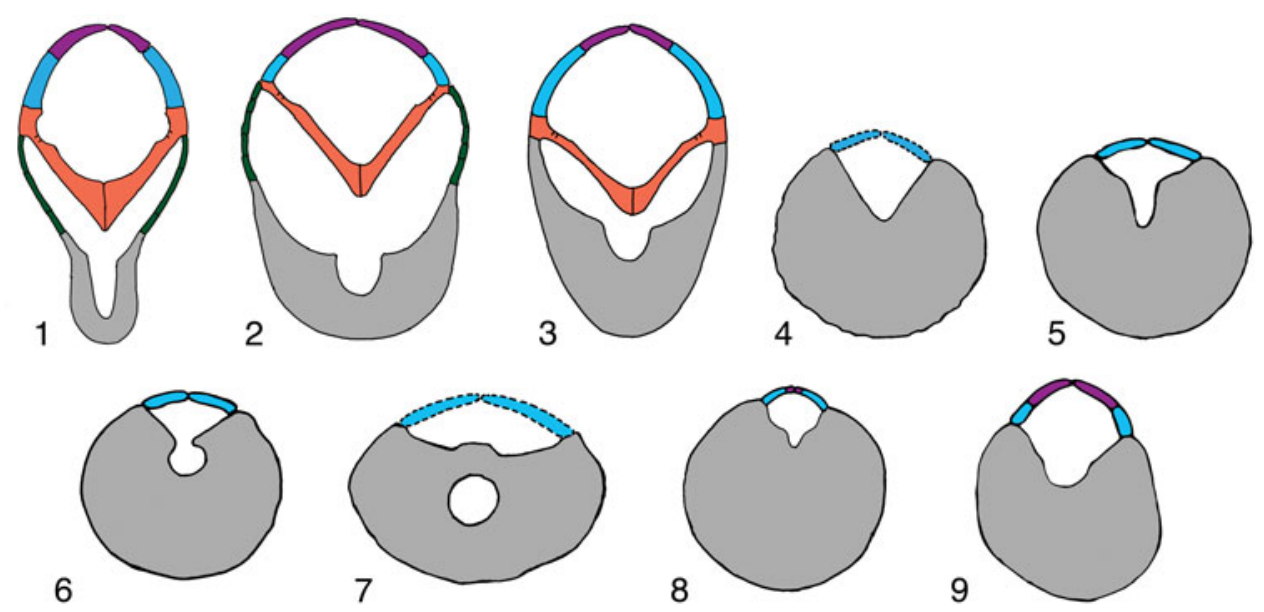

Figure 7. Schematic cross sections of representative Tremadocian (1-3) and Sandbian (4-9) crinoid arms showing morphologic change through time, secondary grooves in aboral channels, much enlarged, homologous elements color coded as in Figure 6: (1) cladid-like Apektocrinus ubaghsi Guensburg and Sprinkle, 2009, 1983TX1; (2) camerate-like Titanocrinus sumralli Guensburg and Sprinkle, 2003, PE 52720; (3) disparid-like Athenacrinus broweri n. gen. n. sp., paratype PE 52753; (4) rhodocrinitid camerate Archaeocrinus snyderi Guensburg, 1984, unnumbered brachial on same slab with UI X-5738; (5, 6) disparid Doliocrinus pustulatus Warn, 1982, brachial outline from 1113TX51 and 1279TX177, showing transition from secondary groove to nearly fully enclosed foramen within brachial, cover plates added from Doliocrinus monilicaulis Guensburg, 1984, UI X-5716; (7) Columbicrinus crassus Ulrich, 1925, UI X-5711, brachial outline from Guensburg (1992); (8) hybocrinid cladid Hybocrinus bilateralis Guensburg, 1984, UI X-5867 and 5868, and (9) cladid Cupulocrinus crossmani Brower, 1992, SUI 62895A and $62895 \mathrm{C}$, secondary groove based on unnumbered specimens of Cupulocrinus gracilis in Field Museum collections. 

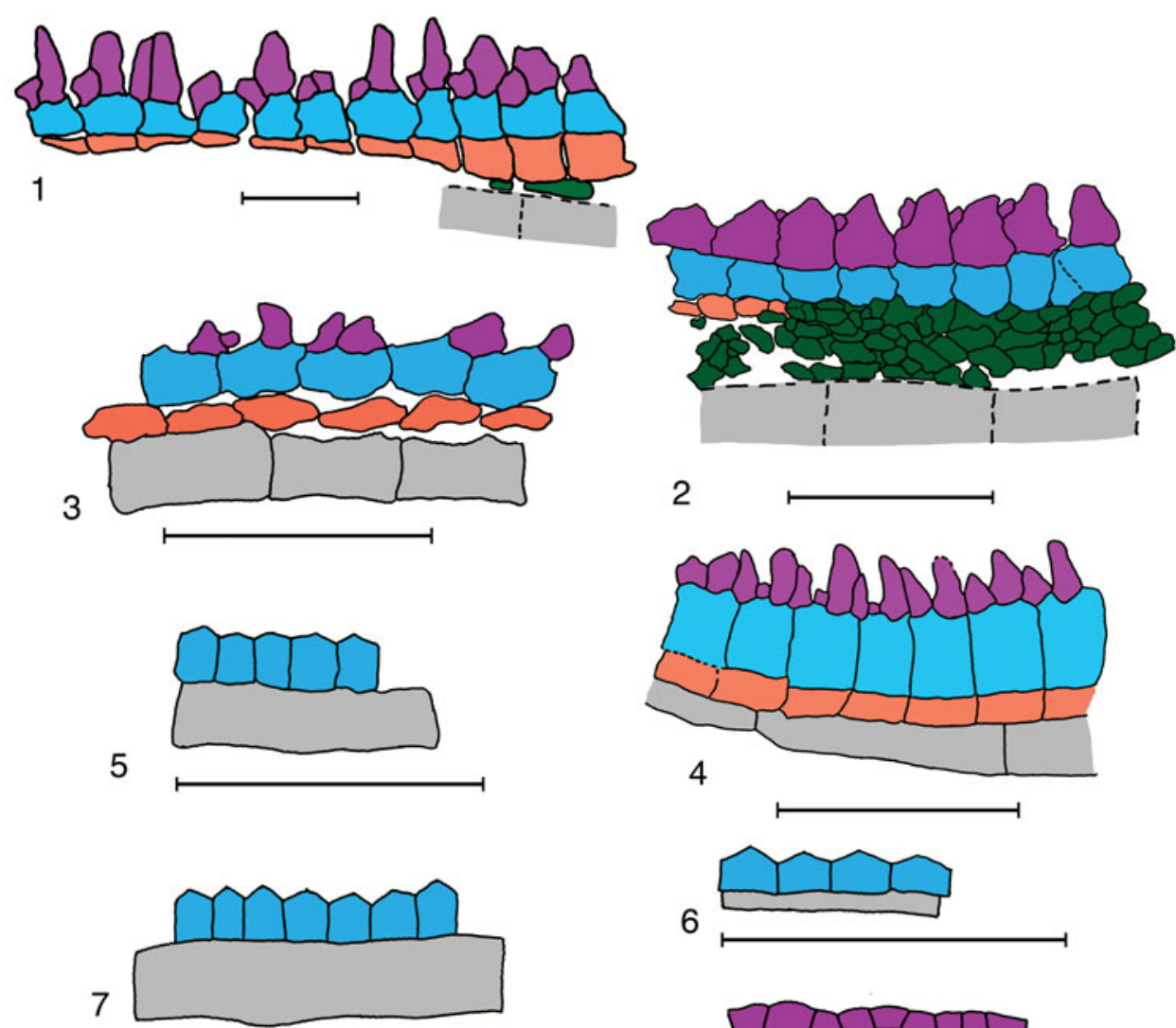

6

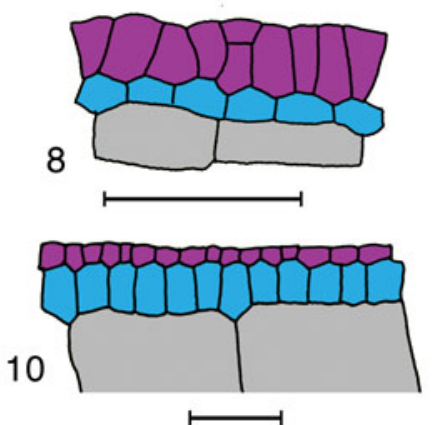

Figure 8. Color-coded tracings of Early (Tremadocian) (1-4) and Late (Sandbian/Katian) (5-10) Ordovician crinoid mid-distal arm segments showing plating from one side: (1, 2) earliest-known crinoids, neither with exposed brachials: (1) Apektocrinus ubaghsi Guensburg and Sprinkle, 2009, 1984TX1, deeply weathered, many elements fragmentary, outlines incomplete, prepared from Figure 1.8; (2) Titanocrinus sumralli Guensburg and Sprinkle, 2003, PE 52720, weathered, most element outlines preserved, floor plates unexposed except on left where laterals have fallen away, traced from Figure 10.6; $(\mathbf{3}, \mathbf{4})$ slightly younger taxa: $(\mathbf{3})$ cladid-like Aethocrinus moorei Ubaghs, 1969, YPM 517777, latex cast, plate outlines partially exposed; (4) disparid-like Athenacrinus broweri $\mathrm{n}$. gen. $\mathrm{n}$. sp., paratype PE 52751, medial cover plates showing primary, secondary, and ?tertiary elements, plate outlines well preserved except for medial cover plates, these slightly weathered, traced from Figure 3.2; (5-10) line drawings modified from Brower (2006, fig. 1): (5) disparid Cincinnaticrinus varibrachialis Warn and Strimple, 1977, MCZ 136884; (6) disparid Ectenocrinus simplex (Hall, 1847), MCZ 133457; (7) camerate Euptychocrinus skopaios Brower, 1994, SUI 80173; (8) cladid Cupulocrinus crossmani Brower, 1992, SUI 62895C; (9, 10) cladid Hybocrinus conicus Billings, 1857: (9) SUI 49484, juvenile with single biseries, and (10) SUI 80030, mature specimen with two-tiered pattern. Color coding as in Figure 6. Scale bars $=1 \mathrm{~mm}$.

$4.5,6,7.1,7.3,8.1,8.3,8.4,10.2,10.8,11.3,11.4)$ (Note: cover plates in general were not illustrated with sufficient clarity to allow interpretation in the works of Guensburg and Sprinkle, 2003, 2009, and other earlier workers. Much of the earlier ambiguity in interpretation has resulted from preservational artifacts and unfavorable orientations. Preparation of previously collected and well-preserved material such as that of Athenacrinus $\mathrm{n}$. gen. has helped to resolve this issue.) Floor plating is largely or fully internal in crinoid arms. They are fully internal in Titanocrinus and possibly Eknomocrinus (Figs. 8.2, 10.5, 10.6, 11.1). If exposed, these are exposed along the lateral margins of the ambulacra (Fig. 10.2, 10.7,
10.8). Podial basins range from round in the cladid-like Apektocrinus and possibly Aethocrinus (Guensburg and Sprinkle, 2009, fig. 7.3; Fig. 10.7) to wedge-shaped in the disparid-like Athenacrinus n. gen. described here (Fig. 4.4; Table 1).

Extraxial lateral plates.-The extraxial skeletal region of the earliest crinoids consists of brachials and lateral plate pavements, fields of small plates separating the brachials from the axial skeleton oral to these fields. The extraxial lateral plates are thin and extend to the arm tips in the camerate-like Titanocrinus (Fig. 10.5) and at least to the 


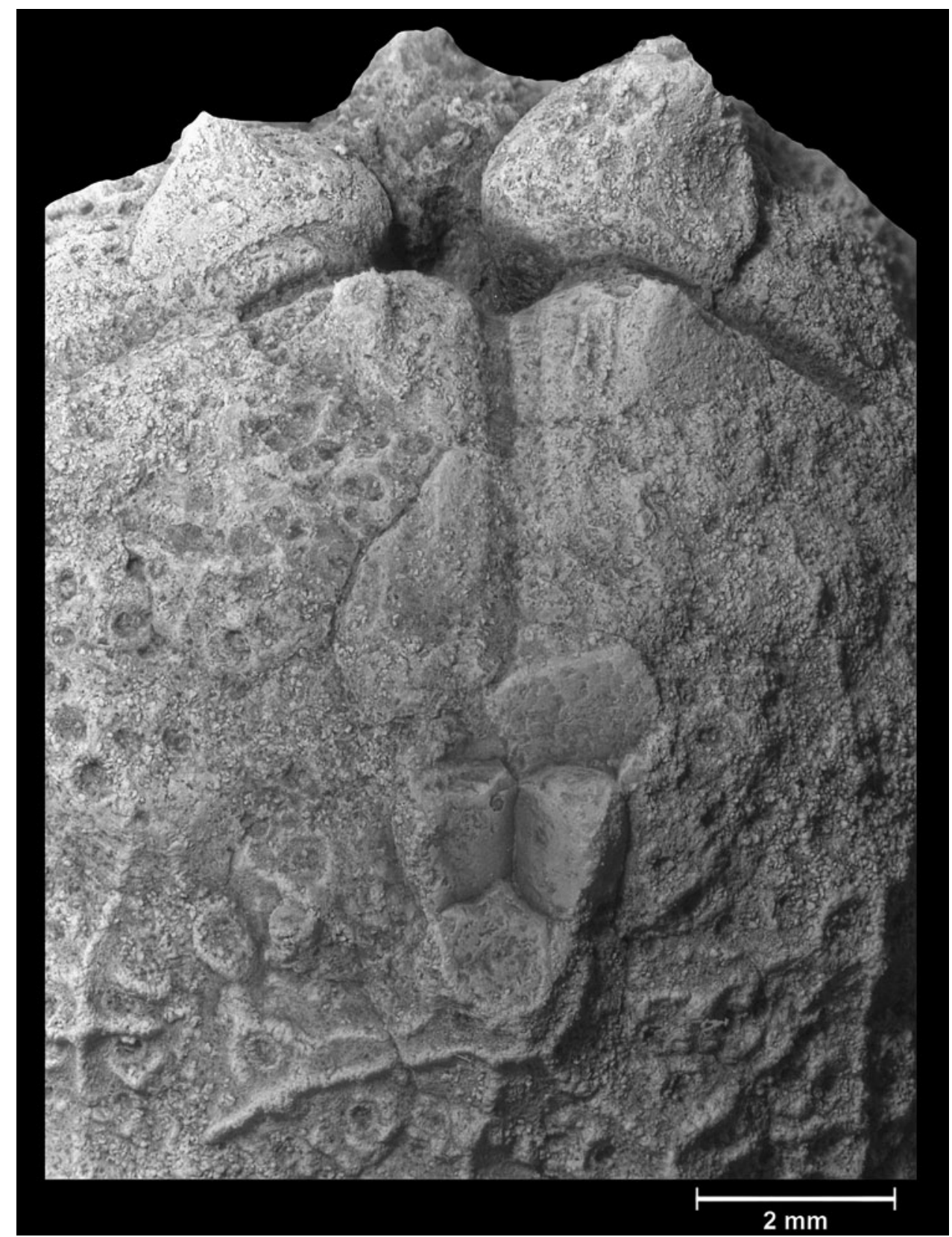

Figure 9. Eumorphocystis multiporata Branson and Peck, 1940, a diploporan blastozoan; OU 9048, view of E ray, broken surface adjacent to the thecal wall, no opening to the thecal interior.

midarm in the cladid-like Aethocrinus and Apektocrinus (Guensburg and Sprinkle, 2009, figs. 1.2, 2; Guensburg et al., 2016, fig. 5E; Fig. 10.1). In these cases, the axial skeleton (cover and floor plates) lies oral to (above in life position) the brachial (adoral) channel. Extraxial lateral plate fields are lacking in Alphacrinus, Athenacrinus n. gen., and other early disparids (Figs. 3.1, 3.2, 3.4, 8.4, 11.3 , 11.4). Floor plates are concealed beneath lateral plates in Titanocrinus, Eknomocrinus, Alphacrinus, and possibly an undescribed Floian disparid (Figs. 3.2-3.4, 10.3, 10.5, 10.6; Table 1), but their edges are laterally exposed in Apektocrinus, Aethocrinus, and most Athenacrinus n. gen. (Guensburg and Sprinkle, 2009, fig.
1.2; Figs. 3.1, 3.3, 3.4, 4.2, 4.5, 8.1, 8.3, 8.5, 10.8, 11.3, 11.4). In these instances, arm floor plates rest directly upon brachials and nestle into the adoral channel. The adoral channel in earliest crinoids contains a secondary medial groove that might have housed the brachial nerve (Figs. 4.5-4.7, 7.1-7.3).

Later transformations. - The Tremadocian pattern transitioned to more standard Paleozoic patterns during the Floian. Changes included: (1) extraxial lateral field size reduction or disappearance, (2) floor plates nestling into the adoral channel, but later not expressed as skeletal elements, and (3) medial cover plates consisting of a single biseries or entirely absent. 


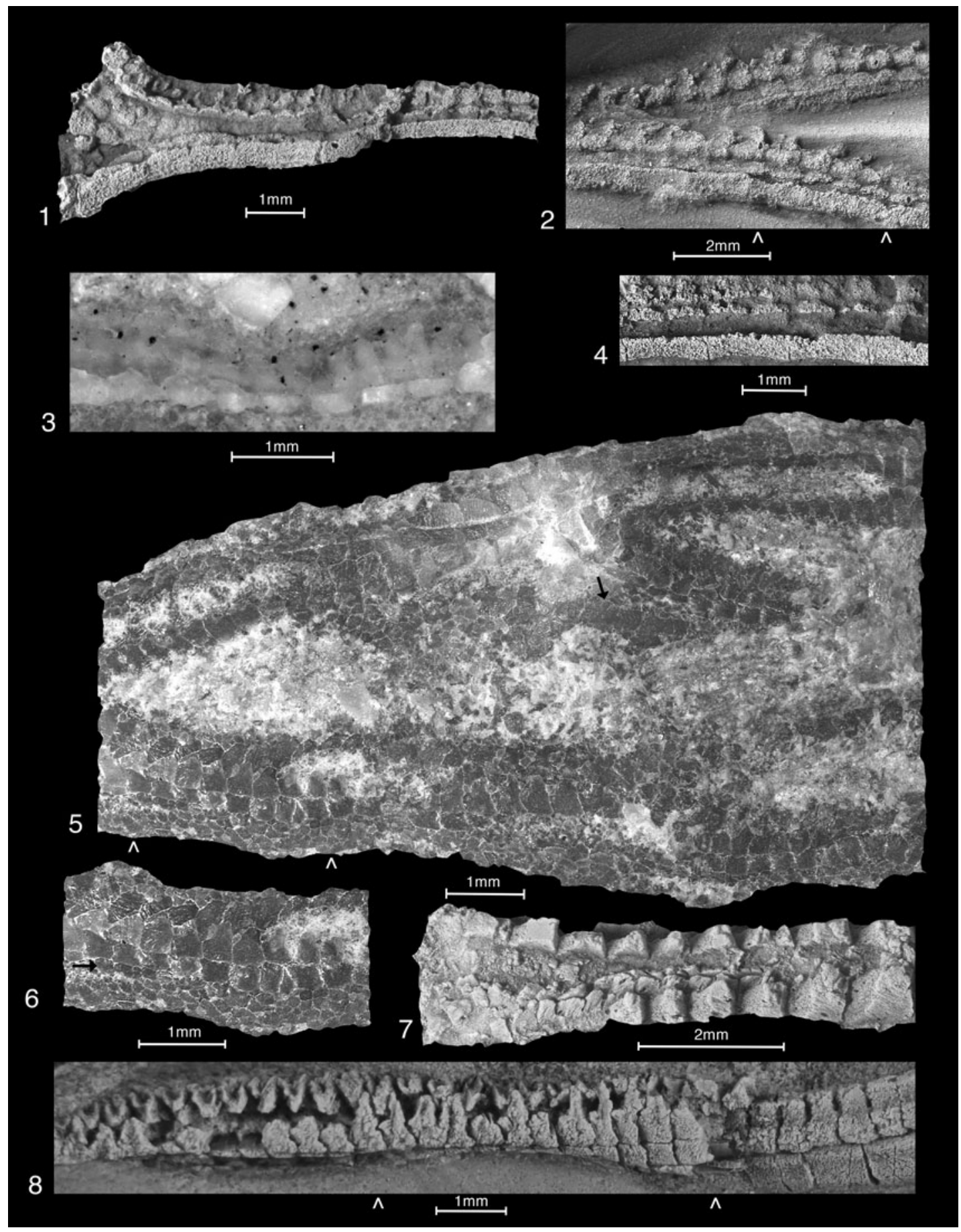

Figure 10. Cover and floor plates of Tremadocian crinoids: (1, 2, 4) cladid Aethocrinus moorei Ubaghs, 1969: (1, 4) MNHN A49684: (1) tegmen to arm transition showing collapsed delicate platelet pavement separating brachials from floor plates that line the arm interior; (4) floor plate series above brachials, showing podial pores; (2) YPM 517777, brachials, floor plates, large lateral cover plates, medial cover plates partly disarticulated, with chevrons = position of Figure 6.3; (3) camerate-like protocrinoid Titanocrinus sp., PE 52722, medial arm, brachials weathered away revealing floor plates with podial pores or basins; (5, 6) Titanocrinus sumralli Guensburg and Sprinkle, 2003, holotype PE 52720, dry uncoated: (5) distal arm showing flattened, splayed lateral pavement, isotomous branching, with arrow $=$ brachials, chevrons $=$ position of Figures 1.6 and 5.2; (6) enlargement from (5); plating, in order from below: laterals, exposed floor plates indicated by arrows at left, lateral cover plates, medial cover plates, and medial cover plates of opposite side; (7) Titanocrinus sp., PE 52727, arm weathered through from back revealing floor plates; (8) Apektocrinus ubaghsi Guensburg and Sprinkle, 2009, 1983TX1, large lateral cover plates, alternating double biseries of medial cover plates on left, floor plates with podial pores on right, coated, with chevrons = position of Figure 8.1.

This pattern persists into the Late Ordovician and beyond (Table 2). Diminutive taxa, and those with pinnulate morphology (e.g., Celtocrinus Donovan and Cope, 1989, Proexenocrinus Strimple and McGinnis, 1972) express a single cover plate tier or biseries. Juvenile Hybocrinus conicus Billings, 1857 are single-tiered, but the adults are two-tiered (Brower, 2006, fig. 1), suggesting paedomophosis as a mechanism for the reduction of tier numbers in other taxa. 


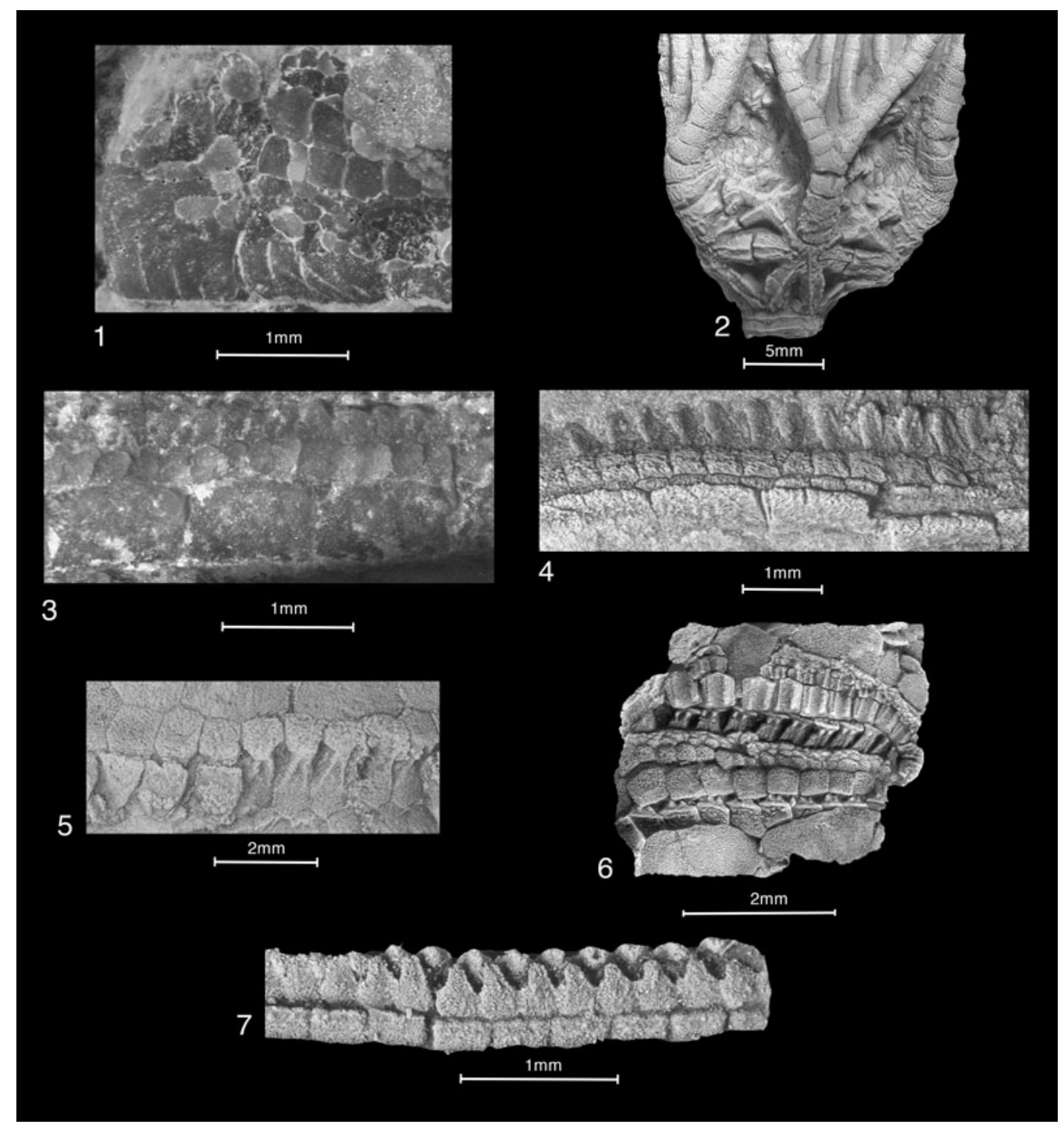

Figure 11. Axial construction of early crinoids, edrioasterid edrioasteroids, and a representative early blastozoan brachiole: (1) Eknomocrinus wahwahensis Guensburg and Sprinkle, 2003, holotype PE 52734; (2, 3) Alphacrinus mansfieldi Guensburg, 2012, holotype PE 52743: (2) tegmen showing articulating cover plates, coated; (3) medial arm detail, two-tiered cover plating, medial cover plates with double alternating biseries, uncoated, dry; (4) undescribed Early Floian iocrinid, PE 52757, naturally etched showing, from below, brachials, floor plates, lateral and medial cover plates; (5) Paredriophus elongatus Guensburg and Sprinkle, 1994, PE 52755, exposed floor plates, podial basins with pores on right, coated; (6) Pseudedriophus guensburgi Sprinkle and Sumrall, 2015, 1778TX16, large rectangular lateral cover plates over partly exposed floor plates, smaller medial cover plates arranged with larger elements contacting laterals and much smaller elements along the perradial suture, coated; (7) Gogia sp., NPL 93360, brachiole showing single biseries of cover plates.

Patterns of taxonomic distribution suggest that cover plate transformations occurred asynchronously among major clades, these having emerged during the Tremadocian. The secondary medial groove submerges to become a longitudinal foramen fully encased in brachials by the Late Ordovician among disparids (Figs. 7.5-7.7), but not among cladids or camerates (Fig. 7.4, 7.8, 7.9).

\section{Disproportionate cup ray plating in disparid crinoids: 'Compound radials' and 'biradials'}

Athenacrinus n. gen. is the oldest crinoid expressing disproportionate cup-ray plating, and evidence from this taxon provides a hypothesis for the origin of this morphology. This unusual trait of many early disparids is a tendency to express disparate, uneven cup plating in which some rays possess one or two offset plates forming interlocking patterns with adjacent rays. Moore and Laudon (1943) created compound radial ('biradial') terminology for those rays with two cup plates; proximal elements were termed 'inferradials,' and distal elements 'superradials.' This terminology has become entrenched in family-level taxonomy in disparids and remains in common usage today (Ausich, 2018), yet there is no evidence that this interpretation is correct. Initial ray plates in Athenacrinus $\mathrm{n}$. gen. are all large, similar to those of iocrinid radials. The second, more distal, $\mathrm{C}$ ray plate is smaller than the radial but still cup-like, carrying both an arm and anal column above. If multiple fixed-ray plating constitutes an emergent crinoid apomorphy as is now supported by the Tremadocian crinoid record, then this plate should be termed the first fixed primibrachial, with its cup-like appearance inherited 
Table 1. Summary of earliest crinoid axial morphologies. Compagicrinus is early or middle Floian in age, younger than the other taxa listed here. The undescribed iocrinid is late Tremadocian and associated with specimens of Aethocrinus moorei Ubaghs, 1969 from Morocco.

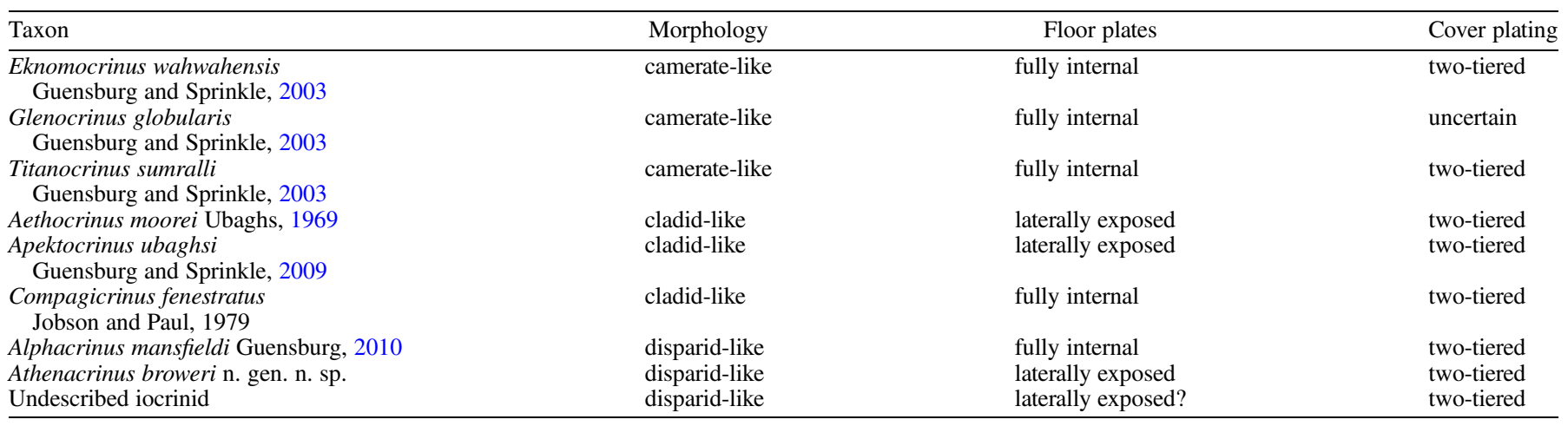

from deeper in crinoid phylogeny. The same reasoning can be used for the E ray of Athenacrinus $\mathrm{n}$. gen. (Figs. 1.5, 5.2).

\section{Independent origins of crinoids and blastozoans among early radiate echinoderms}

Basis of phylogenetic analysis.-A parsimony analysis using PAUP (Swofford, 2003) was constructed expressly to: (1) test the independent monophyly of crinoids and blastozoans and how these major clades are related to each other, and (2) reconstruct phylogenetic relationships among the earliest, Tremadocian, crinoids. This analysis is not intended to establish crinoid phylogeny beneath the subclass level. It differs from that of Ausich et al. (2015b) whose assumptions concerning crinoid origin lead to rooting on multiple blastozoan taxa. It also differs from the analyses of Guensburg (2012), Cole (2017), and Wright (2017), all of which are rooted on Tremadocian crinoids, but omit, or make unsupported assumptions concerning crucial early crinoid taxa.

There remains no known immediate crinoid sister group. Taxa chosen for this analysis, with three exceptions, are Tremadocian, Early Ordovician, or earlier, this constraint intended to minimize effects of homoplasy caused by the origination of more crownward apomorphies. This is an important consideration given that stalked echinoderms-both blastozoans and crinoids-occupied similar ecologic niches and diversified rapidly during the Ordovician (Guensburg et al., 2016).

As ever, central to the dispute over crinoid origins is the question of whether given features are homologous or homoplastic. Historically, very similar terminologies have been used interchangeably for blastozoans and crinoids (for summaries, see Guensburg and Sprinkle, 2007; Sumrall and Waters, 2012). Argumentation challenging potential homologies based on congruency, conjunction, and similarity arguments (ambulacral floor and cover plating excepted, see subsequent paragraph) has been laid out in detail (Guensburg and Sprinkle, 2007, 2009; Guensburg et al., 2010, 2016). These findings are accepted here.

The analysis was rooted on a middle Cambrian edrioasteroid-like form, Stromatocystites pentangularis Pompeckj, 1896 (see Zamora et al., 2015). This taxon is here considered to approximate an archaic, pentaradiate level of organization. Another early pentaradiate, Kailidiscus chinensis Zhao et al., 2010, was included because of its atypical ambulacral morphology and exceptional preservation. Camptostroma roddyi Ruedemann, 1933, an early difficult-to-interpret archaic radiate taxon is included because it is an edrioasteroid-like form, but with short arms (Durham, 1966, text-fig. 1; 1967, fig. 396, 1b). This fossil is under fuller and more accurate revision (Derstler et al., 2018), but information is now sufficient to analyze most salient features that significantly improve upon previous

Table 2. Characteristic arm types and cover plates among diverse Late Ordovician crinoids (primarily from Brower, 2006 and Sprinkle, 1982a, b).

\begin{tabular}{|c|c|c|c|}
\hline Species & Major group & Arm morphology & Cover plate tiers \\
\hline Archaeocrinus subovalis Strimple, 1953 & camerate & pinnulate & 1 \\
\hline Euptychocrinus skopaios Brower, 1994 & camerate & pinnulate & 1 \\
\hline Raphanocrinus subnodosus (Walcott, 1884) & camerate & pinnulate & 1 \\
\hline Reteocrinus variabilicaulis Guensburg, 1984 & camerate & non-pinnulate & 2 \\
\hline Carabocrinus treadwelli Sinclair, 1945 & cladid & non-pinnulate & 2 \\
\hline Cupulocrinus crossmani Brower, 1992 & cladid & non-pinnulate & 2 \\
\hline Hybocrinus nitidus Sinclair, 1945 & cladid & non-pinnulate & 2 \\
\hline Hybocrinus bilateralis Guensburg, 1984 & cladid & non-pinnulate & 2 \\
\hline Hybocrinus conicus Billings, 1857 & cladid & non-pinnulate & 2 \\
\hline Palaeocrinus hudsoni Sinclair, 1945 & cladid & non-pinnulate & 2 \\
\hline Porocrinus bromidensis Sprinkle, 1982b & cladid & non-pinnulate & 2 \\
\hline Praecupulocrinus conjugans Brower, 1992 & cladid & non-pinnulate & 1 \\
\hline Quinquecaudex glabellus Brower and Veinus, 1982 & cladid & non-pinnulate & 2 \\
\hline Apodasmocrinus daubei Warn and Strimple, 1977 & disparid & pinnulate & 1 \\
\hline Cincinnaticrinus varibrachialis Warn and Strimple, 1977 & disparid & non-pinnulate, ramulose & 1 \\
\hline Cremacrinus ramifer (Brower, 1966) & disparid & non-pinnulate, ramulose & 1 \\
\hline Ectenocrinus simplex (Hall, 1847) & disparid & pinnulate & 1 \\
\hline Peltacrinus sculptatus Warn, 1982 & disparid & non-pinnulate & 2 \\
\hline
\end{tabular}


interpretations (Durham, 1966; Paul and Smith, 1984). We do not accept the reconstruction of Paul and Smith (1984, fig. 5), and instead conclude, based on more complete material, that Camptostroma was a low, biscuit-shaped form with a short, projecting, pedunculate aboral extension and with coelomate arms projecting along the margins of the theca (Derstler, et al., 2018). Two edrioasterid edrioasteroids-'Totiglobus' lloydi Sprinkle, 1985, from the middle Cambrian, and Pseudedriophus guensburgi Sprinkle and Sumrall, 2015, from the Early Ordovician-were included based on similar axial expressions with earliest crinoids. Blastozoans cited by some to include the crinoid ancestor and six diverse taxa, spanning a long stratigraphic range, were coded. These include: $(1,2)$ the stem early Cambrian forms Kinzercystis durhami Sprinkle, 1973 and Lepidocystis wanneri Foerste, 1938 (see Sprinkle, 1973); (3) the middle Cambrian gogiid Gogia kitchnerensis Sprinkle, 1973; (4) the Tremadocian, Early Ordovician 'eocrinoid' Rhopalocystis destombesi Ubaghs, 1963 (see Ubaghs, 1968); (5) the rhombiferan-like Macrocystella (see Paul, 1968); and (6) the Sandbian diploporan blastozoan Eumorphocystis multiporata (see Parsley, 1982). The last taxon constitutes an exception to our stratigraphic constraint but was included because of recent claims that it represents a sister taxon to the Crinoidea (see above discussions concerning the origin of the crinoid arm). All crownward blastozoans express highly derived autapomorphies in thecal plating that have no supportable homologies among crinoids, and these were omitted from the data matrix. The early stylophoran Ceratocystis perneri Jaekel, 1901 (see Ubaghs, 1967) was included to extend the range of morphologies tested in the analysis. All seven described Tremadocian crinoids were coded: (1) Aethocrinus moorei Ubaghs, 1969; (2) Alphacrinus mansfieldi Guensburg, 2012; (3) Apektocrinus ubaghsi Guensburg and Sprinkle, 2009; (4) Athenacrinus broweri n. gen. n. sp.; (5) Eknomocrinus wahwahensis Guensburg and Sprinkle, 2003; (6) Glenocrinus globularis Guensburg and Sprinkle, 2003; and (7) Titanocrinus sumralli Guensburg and Sprinkle, 2003. Hybocrinus nitidus Sinclair, 1945 (see Sprinkle, 1982a) and Carabocrinus treadwelli Sinclair, 1945 (see Sprinkle, 1982b), of the Late Ordovician Sandbian, have been described as plesiomorphic taxa whose axial morphologies provide homologies and phylogenetic linkages with Eumorphocystis (most recently, see Sheffield and Sumrall, 2019a, b). Therefore, we also included these exceptions to our stratigraphic constraint. A total of 21 taxa from all groups were included in this analysis.

Characters in this analysis are described below using body region terminology from the Extraxial Axial Theory (EAT) (Mooi and David, 1998; David et al., 2000). An important issue of this study is the definition of so-called 'true arms,' these involved in the coding of at least 16 characters. We concur with previous studies (Mooi and David, 1998; Guensburg et al., 2010, 2016) that identified the absence of somatocoel-bearing arms as arguably the key character separating blastozoans from all other pentaradiate echinoderms, including crinoids. This crucial distinction is manifested in the axial skeletons of blastozoan and crinoid arms. The primary supports in blastozoan appendages are axial elements (floor plates, brachiolars), whereas the primary supports in crinoid arms are extraxial (brachials). In addition, the well-documented complexity of ontogeny and anatomy seen in crinoid arms (Heinzeller and
Welsch, 1994; Guensburg et al., 2016; and others), and the interplay of skeletal, water vascular, and coelomic elements in their formation make feeding appendages such as arms character-rich sources of homology that are more likely to carry phylogenetic signal. Therefore, the number and source of characters upon which our analysis relies reflect both the complexity and the fundamental differences among major echinoderm clades. Thirty-four characters were coded:

(1) Left and right somatocoels: underlying ambulacra along their entire length (0); restricted to thecal interior (1). State (0) includes those arm-bearing taxa with cavities extending uninterrupted from the thecal shoulders. This trait, from a practical standpoint, highlights a key difference in feeding appendage construction. State (1) includes cases in which cavities do not pass through the thecal shoulders, but rather continue onto the theca between or within ambulacrals (floor plates) (Sprinkle, 1973; Guensburg et al., 2010).

(2) Podial pores or basins: present (0); absent (1). Determining the existence of podial pores or podial basins is crucial to assessing relationships among early crinoids, as well as with other early echinoderm groups. Fossils can be difficult to interpret in which weathering and diagenesis obscure plate boundaries, as in the fossils treated here (see Taphonomy and preparation, above). The best supported interpretation, obtained by coated, submersed, dry images, is that there are at least podial basins if not actual pores in basins that extend to water vascular elements inside the coelom, internal to the floor plates. Although not documented in later Paleozoic crinoids, these structures can be seen in Aethocrinus, Athenacrinus n. gen., Apektocrinus, Titanocrinus, and possibly Glenocrinus (Figs. 10, 11).

(3) Floor plates on the theca: short, relatively wide (0); long, relatively narrow (1). This trait does not code for appendage morphology.

(4) Floor plates in appendages: thin, slat-like, not providing primary appendage supports (0); thick, blocky, forming primary appendage skeletal supports (1).

(5) Ambulacral cover plates: arranged in lateral and medial tiers (0); arranged in a single biseries of lateral plates (medial tier not expressed) (1). Medial and lateral tiers were previously referred to as primary and secondary cover plates (Paul and Smith, 1984).

(6) Medial cover plates: overlapping elements diminishing in size as they arc over the perradial suture (0); an alternating double biseries (1). This character requires medial cover plates and is scored as inapplicable for those taxa lacking medial cover plates.

(7) Hinging of thecal (nonappendage) cover plates: hinged, capable of opening and closing (0); fixed, forming closed ambulacral tunnels (1).

(8) Axial orals: absent (0); expressed as differentiated interradial elements surrounding the peristome in all interrays and forming junctions of ambulacra (1). Axial orals are not regarded as homologous with similarly positioned, extraxial, oral-like plates such as those of modern crinoids or of Hybocrinus nitidus and Carabocrinus treadwelli (for supporting argumentation, see Guensburg et al., 2016). Further, earliest hybocrinids lack orals entirely, suggesting 
an acquisition independent from (and therefore not homologous with) the orals of blastozoans, e.g., Eumorphocystis (Guensburg and Sprinkle, 2017). The plating of the oral region of Stromatocystites pentangularis includes oral-like plating in AB and EA interrays. This latter state is autapomorphic among the taxa studied and was omitted from the analysis.

(9) Brachioles: absent (0); present (1). Brachioles are entirely axial in construction whether uniserial or biserial, their primary support structures always arising from (axial) floor plates or representing extensions of those floor plates beyond the perforate extraxial region.

(10) Fixed rays: contacted entirely by nonstandardized plating (0); contacted by standardized circlet(s) in part or entirely (1). Fixed rays are the uniserial series continuous with the primary appendage support plate series. This character is inapplicable for those taxa lacking 'true' arms sensu David and Mooi (1999, p. 92) and David et al. (2000, p. 354).

(11) Respiratory pores: epispires (0); absent (1); diplopores (2). State (1) includes taxa with thin, often corrugated, stereom at plate corners.

(12) Thecal base circlet: absent (0); present as a plate collar of many (> 5) plates (1); present with five infrabasal plates (2); present with four plates (3); present with a single fused element (4). State (1) consists of a ring of larger thecal plates above a narrower, pinched, pedunculate zone.

(13) Dorsal cup: conical (0); bowl-shaped (1). The term 'dorsal cup' requires left and right somatocoels extending from the thecal shoulders (character 1 above). This character is inapplicable for those taxa lacking 'true' arms sensu David and Mooi (1999, p. 92) and David et al. (2000, p. 354) (see character 19).

(14) CD interradius elevation: not expressed except for periproct or anal cone (0); long cylindrical sac (1).

(15) CD interradial gap plate: present (0); absent (1). This character requires the presence of true arms. State $(0)$ requires extension of the CD interray gap to the stem/stalk, i.e., they interrupt the cup base circlet. Gap plates are relatively small and are inserted between an otherwise more or less regular thecal base circlet (character 12).

(16) True basals: absent (0); expressed as a differentiated midcup circlet between infrabasals, if present, and true radials (1). State (1) requires the presence of true arms and is therefore marked as not applicable in cases when true arms are absent (see character 19).

(17) Secondary median groove: absent (0); expressed in feeding appendages (1). State (1) refers to a subsidiary channel along the interior aboral surface of the presumed coelomic channels in feeding appendages and extending from the theca. This groove could have housed the brachial nerve.

(18) True radials: absent (0), present (1). A true radial represents the proximalmost extraxial plate of a true arm ray series. These support free arms at least early in ontogeny. This character requires the presence of true arms and is therefore marked inapplicable in cases in which true arms are absent. Eumorphocystis expresses extraxial elements superficially similar to true radials of the type seen in derived crinoids in which radials form the cup top. Unlike crinoids, the Eumorphocystis plates are not located at the cup top (see Sheffield and Sumrall, 2019a) and facets have no coelomic notches or other evidence of any communication to the thecal interior.

(19) Left and right somatocoels extended off the theca in feeding appendages, thus forming true arms: absent (0), present (1).

(20) True arm branching pattern: True arms atomous, nonbranching (0); true arms isotomously branching (1); true arms endotomously branching (2). This character is scored inapplicable for taxa lacking true arms.

(21) Brachials: absent (0); present (1). Brachials, when expressed, constitute primary skeletal supports for the feeding appendages. This character requires true arms and is scored inapplicable for taxa lacking true arms. Eumorphocystis expresses uniserial backing plates superficially resembling brachials, but these do not form primary appendage supports and do not contain a through-going coelomic canal.

(22) Extraxial laterals: present, accompanying extended thecal wall out arms (0); absent (1). Extraxial laterals, when present, occupy aboral arm surfaces aside from brachials. State $(0)$ requires true arms and is scored inapplicable for taxa lacking true arms.

(23) Platelet webs at branchings: present (0); absent (1). These plate fields are most parsimoniously regarded as extensions of extraxial lateral plating (see character 22). This character requires true arms and is scored inapplicable for taxa lacking true arms.

(24) Fixed brachials: present (0); absent (1). Fixed brachials are ray plates that extend aborally from true radials and are embedded in the cup; they articulate laterally with interradial plates. This character requires true arms and is scored inapplicable for taxa lacking true arms.

(25) Cup-like fixed brachials: three or more in all rays (0); none to two in all rays (1); cup-like fixed brachials in C or E rays only (2). Cuplike indicates that the plates are embedded in the cup with margins flush with adjacent cup plates, much like radials. This character requires true arms and is therefore scored inapplicable for taxa lacking true arms. Polarity is established by the known crinoid record.

(26) One or more brachial pairs in lateral union above branchings: present (0); absent, not paired above branchings (1). This character requires true arms and is therefore scored inapplicable for taxa lacking true arms.

(27) Interradial plate fields separating multiple fixed primibrachials: much wider than fixed rays (0); not as wide as fixed rays or absent (1); absent (2). Width is measured across the widest portion of the field and is compared with the widest fixed brachial. This character requires true arms and is therefore scored inapplicable for taxa lacking true arms.

(28) CD interradius: extending downward to the base of the thecal cavity (0); ending at true radials (1). State (0) indicates that the radial circlet is interrupted across the CD interradius, and state (1) indicates that radials are contiguous below the $\mathrm{CD}$ interradius. This character requires true arms and is therefore scored inapplicable for taxa lacking true arms.

(29) Radianal(s) and anal X plates: absent (0); present (1). State (1) consists of differentiated plates occupying the space below and to the left of a 'raised' $\mathrm{C}$ radial. The radianal can be absent in later, more derived taxa, but not in those treated here. States 
(0) and (1) require presence of true arms and is therefore scored as not applicable for those forms lacking them.

(30) Anibrachial plate: absent (0); present (1). This character requires true arms and is therefore scored inapplicable for those taxa lacking true arms.

(31) Peduncle, stem, or stalk: absent or only slightly developed as attachment structure (0); anisotropic, imbricate, plated peduncle (1); irregularly tessellated peduncle with pinched demarcation at base of theca (2); monomeric (holomeric) stem (3); pentameric stalk (4). Carabocrinus treadwelli and Hybocrinus nitidus pentameres are inconspicuous (see Sprinkle, 1982a, figs. 45D, 46H).

(32) Stalk/stem lumen: absent (0); round or irregular trilobate in cross section (1); pentalobate in cross section (2). This
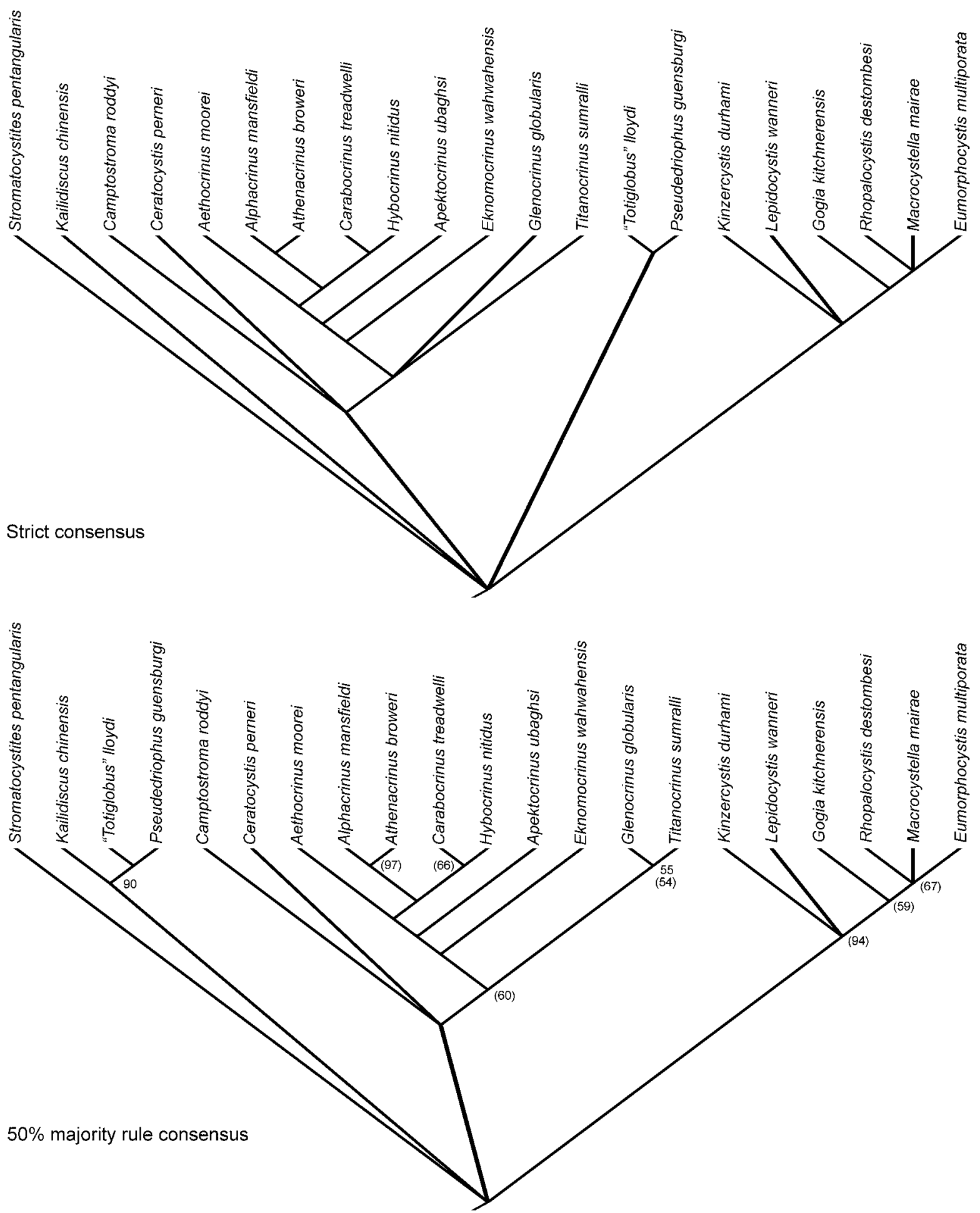

Figure 12. Strict and 50\% majority rule consensus trees for parsimony analysis of matrix in Table 3 . All node frequencies occur in $100 \%$ of trees except where indicated, and bootstrap values are indicated by numbers in parentheses. 
Table 3. Matrix used in phylogenetic analysis.

\begin{tabular}{|c|c|c|c|c|c|c|c|}
\hline Stromatocystites pentangularis Pompeckj, 1896 & 00000 & $0000-$ & $00-0-$ & $-0-0-$ & ---- & $-\ldots$ & $0-00$ \\
\hline Kailidiscus chinensis Zhao et al., 2010 & $000-0$ & $0000-$ & $10-0-$ & $-0-0-$ & $-\ldots$ & $-\ldots$ & $0-0$ ? \\
\hline Camptostroma roddyi Ruedemann, 1933 & 00000 & 00000 & $00-0-$ & ---10 & $00---$ & $-\ldots$ & $0-0-$ \\
\hline 'Totiglobus' lloydi Sprinkle, 1985 & 00000 & $0010-$ & $10-0-$ & $--0-$ & $---_{-}^{-}$ & $-\ldots$ & $0-00$ \\
\hline Pseudedriophus guensburgi Sprinkle and Sumrall, 2015 & 00000 & $0010-$ & $11-0-$ & $-0-0-$ & $-\ldots$ & $-\ldots$ & $2-00$ \\
\hline Kinzercystis durhami Sprinkle, 1973 & 11111 & $-001-$ & $00-0-$ & $-0-0-$ & $-\ldots$ & $-\ldots$ & $1-00$ \\
\hline Lepidocystis wanneri Foerste, 1938 & 11111 & $-001-$ & $00-0-$ & $-0-0-$ & $-\ldots$ & $-\ldots$ & $1-00$ \\
\hline Gogia kitchnerensis Sprinkle, 1973 & 11111 & $-001-$ & $00-0-$ & $-0-0-$ & $-\ldots$ & $-\ldots$ & $2-10$ \\
\hline Rhopalocystis destombesi Ubaghs, 1963 & 11111 & $-011-$ & $04-00$ & $-0-0-$ & $-\ldots$ & $-\ldots$ & 3110 \\
\hline Macrocystella mairae Callaway, 1877 & $1111 ?$ & $-011-$ & $13--0$ & $-0-0-$ & $-\ldots$ & $-\ldots$ & 3110 \\
\hline Eumorphocystis multiporata Branson and Peck, 1940 & 11111 & $-011-$ & $23-00$ & $-0-0-$ & $-\ldots$ & $-\ldots$ & 3110 \\
\hline Ceratocystis perneri Jaekel, 1901 & $00--1$ & $0000-$ & $00---$ & -1010 & 10100 & --00 & $0--0$ \\
\hline Aethocrinus moorei Ubaghs, 1969 & $00 ? 00$ & 10001 & 12001 & $1 ? 111$ & 10010 & 01110 & $420 ?$ \\
\hline Alphacrinus mansfieldi Guensburg, 2012 & $0 ? ? 00$ & 10001 & 12011 & $0 ? 112$ & 11012 & 11101 & 4200 \\
\hline Apektocrinus ubaghsi Guensburg and Sprinkle, 2009 & 00000 & 10001 & 12000 & 11110 & 10010 & -0010 & 4201 \\
\hline Athenacrinus broweri n. gen. n. sp. & 00000 & 10001 & 12011 & 01112 & 11012 & 11101 & 4200 \\
\hline Carabocrinus treadwelli Sinclair, 1945 & $0 ? ?-0$ & 10001 & 12001 & 10111 & 10101 & 12110 & 4201 \\
\hline Hybocrinus nitidus Sinclair, 1945 & 00000 & 10001 & 10001 & 10110 & 11101 & 12110 & 4201 \\
\hline Eknomocrinus wahwahensis Guensburg and Sprinkle, 2003 & $0 ? ? ? 0$ & 10001 & 12100 & $1 ? 111$ & 10010 & 00000 & $420 ?$ \\
\hline Glenocrinus globularis Guensburg and Sprinkle, 2003 & $00 ? ? 0$ & 11000 & $1 ? 100$ & $1 ? 111$ & 10110 & 00000 & $420 ?$ \\
\hline Titanocrinus sumralli Guensburg and Sprinkle, 2003 & $00 ? 00$ & 11000 & 02000 & 01111 & 10110 & 00000 & 4200 \\
\hline
\end{tabular}

character requires a stalk or a stem and scored as not applicable for those forms lacking a meric stalk/stem.

(33) Ray length on theca: long, approaching the perforate/imperforate boundary in extraxial body wall (0); short, restricted to the region around peristome and not approaching boundary between perforate and imperforate extraxial body wall (1).

(34) Extraxial 'orals': absent (0); present (1). The interradial circlet bordering the peristome of Hybocrinus nitidus and Carabocrinus treadwelli is considered extraxial and homologous among these and a few other cyathocrinine crinoids (e.g., Porocrinus Billings, 1857, Palaeocrinus Billings, 1859, and others); these are all characterized by flat tegmens of few plates and with a hydropore within a single posterior 'oral.'

These 34 characters were assembled for scoring using Mesquite Version 3.2 (build 801), and the nexus file run on PAUP 4.0a (build 165) for Macintosh. All characters were unordered and unweighted, but two characters were parsimony uninformative. The analysis employed the branch-and-bound algorithm, consensus trees were computed, and a bootstrap analysis of 10,000 replicates was run using a fast heuristic search.

\section{Phylogenetic position of Athenacrinus n. gen. and comments on crinoid phylogeny}

The phylogenetic analysis resulted in 120 most parsimonious trees of length 61 , consistency index (CI) of 0.721 , retention index of 0.856 , rescaled CI of 0.617 , and a homoplasy index of 0.279 . The strict and $50 \%$ majority rule consensus trees are shown in Figure 12, along with the results of the bootstrap analysis. Figure 13 maps known stratigraphic ranges onto this tree.

In general, the axial skeleton has been considered the more conserved because it is consistently associated with suspension feeding (Mooi and David, 1998; Kammer et al., 2013). This suggestion is at least partially borne out by our analysis. The most important features of the discovered topology revolve around the placement of Camptostroma, the distinctiveness of the blastozoans from crinoids, and the placement of Eumorphocystis.
The last not only receives strong support as belonging to the blastozoan clade, it does so as a highly derived blastozoan. As discussed above, the significance of features obtained by detailed analysis of appropriate material of the latter taxon will be treated in a separate work, but its supposed significance in possessing plesiomorphic crinoid features is not supported by our analysis. Otherwise, the crinoids and blastozoans have very little in common, and each forms a separate clade. Camptostroma retains many plesiomorphic features. In part because the origin of brachials, which characterize most true arms, comes later in the crinoid clade, there remains only weak support for the recovery of Camptostroma as sister to the crinoids.

Resolution among crinoid clades is weakly supported. However, it is clear that there is a robust clade consisting of crinoids including even the earliest known taxa. The relationships among camerate, cladid, and disparid clades remains poorly understood, largely because pervasive trends of cup plate simplification in cladids and disparids increase potential for homoplasy. Distinctive posterior morphologies extend deep in crinoid phylogeny, and traditionally provide reliable data for parsing major clades later in crinoid diversification (Guensburg, 2012). We think that this skeletal complex represents underlying, fundamental differences in anatomy, in particular of the hindgut. As such, it is more informative than traits associated with overall simplification of the calyx during radiation of the crinoid clade.

Recently, Wright (2017) applied a Bayesian statistical analysis to early crinoid phylogeny. That study was directed toward early and middle Paleozoic diversification of noncamerate crinoids. Resultant findings inform some aspects of crinoid diversification during that extended time frame, including a Late Ordovician clade consisting of Porocrinus and similar cladid taxa with oral surfaces dominated by large 'oral' plates. However, exclusion of any earliest camerate-like taxa and prior assumptions in that analysis produced results favoring a cladiddisparid clade, without consideration of potential alternatives.

As previously noted, our focus lies in identifying the most parsimonious crinoid ancestor, and in establishing the 


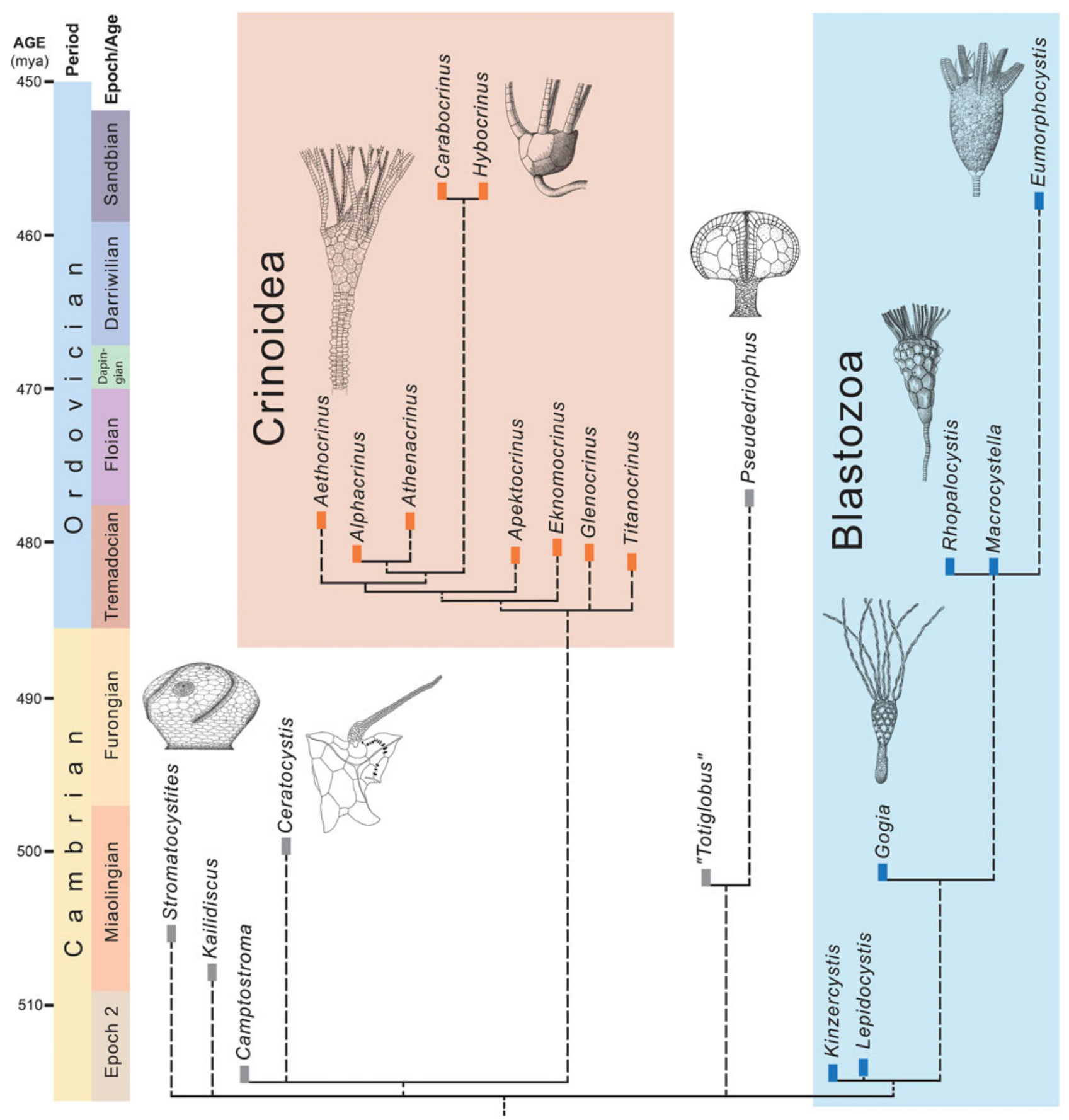

Figure 13. Evolutionary tree based on phylogenetic analysis with stratigraphic occurrence mapped onto it. Earliest occurrence of genera is indicated by dots. In most cases, the known range is as indicated. The crinoid branch includes taxa with feeding appendages supported by extraxial brachials that housed left and right somatocoel extensions. Epispire-bearing aboral plating in Camptostroma "arms" suggests the presence of somatocoels, but without brachial supports. Blastozoan ambulacra extend off of the theca as 'arms' or brachioles, with axial constructs lacking communication with the thecal interior. Series and stage nomenclature follow Geissman et al. (2018). This is an online version of the Geological Society of America Geologic Time Scale, ver. 5.0.

relationships among earliest crinoids, including camerate-like, cladid-like, and disparid-like taxa. Our findings rely on comparative analyses from which a new foundational understanding of earliest crinoid and other aspects of early radiate anatomy have emerged. These discoveries result in fundamentally different interpretations of crinoid ancestry. We suggest that future applications of Bayesian methods targeting these questions should begin with a different set of prior assumptions based upon these discoveries. It is through inclusion of these new data that potential for the Bayesian application as a tool for addressing this basal portion of the echinoderm record can be maximized.

\section{Acknowledgments}

D. Quednau (Field Museum) provided excellent expertise with illustrations. P. Mayer (Field Museum) provided curatorial assistance. S. Lidgard (Field Museum) and P. Mayer offered useful advice. J. Thomas (University of Illinois) provided assistance 
with imagery. M. Florence (Invertebrate Paleontology, Smithsonian Institution, Washington DC) graciously loaned an Athenacrinus broweri $\mathrm{n}$. gen. n. sp. specimen. R. and A. Johns, F. Siewers, D. Sprinkle, and C. Sumrall assisted Sprinkle and Guensburg in the field. We gratefully acknowledge two excellent anonymous reviewers. This paper is a contribution to the International Geoscience Programme (IGCP) project 653, the onset of the Great Ordovician Biodiversification Event.

\section{References}

Ausich, W.I., 2018, Morphological paradox of disparid crinoids (Echinodermata): phylogenetic analysis of a Paleozoic clade: Swiss Journal of Palaeontology, v. 137, p. 159-176, doi:10.1007/s13358-018-0147-z.

Ausich, W.I., and Rozhnov, S.V., 2017, Iocrinid crinoids from the Ordovician of the Baltic Region, Estonia: Paleontological Journal, v. 49, p. 145-152, doi:10.1134/0031030115020069.

Ausich, W.I., Kammer, T.W., Wright, D., Cole, S., Peters, M., and Rhenberg, E., 2015a, Toward a phylogenetic classification of the Crinoidea (Echinodermata), in Zamora, S., and Romano, I., eds., Progress in Echinoderm Paleobiology: Instituto Geológico y Minero de España Cuaderno del Museo Geominero, v. 19, p. 29-32.

Ausich, W.I., Kammer, T.W., Rhenberg, E.C., and Wright, D.F., 2015b, Early phylogeny of crinoids within the pelmatozoan clade: Palaeontology, v. 58, p. 937-952, doi:10.1111/pala.12204.

Billings, E., 1857, New species of fossils from Silurian rocks of Canada: Canada Geological Survey Report of Progress 1853-1856, p. 247-345.

Billings, E., 1859, Crinoidea of the lower Silurian rocks of Canada: Geological Survey of Canada, Canadian Organic Remains, Decade 4, p. 1-72.

Blakey, D., 2019, Deep time maps: Maps of ancient Earth: https://deeptimemaps.com/ (accessed October 2019).

Branson, E.B., and Peck, R.E., 1940, A new cystoid from the Ordovician of Oklahoma: Journal of Paleontology, v. 14, p. 89-92.

Breimer, A., 1978, General morphology, Recent crinoids, in Moore, R.C., and Teichert, C., eds., Treatise on Invertebrate Paleontology, Part T, Echinodermata 2(1): Boulder, Colorado, and Lawrence, Kansas, Geological Society of America (and University of Kansas), p. T9-T58.

Brower, J.C., 1966, Functional morphology of Calceocrinidae with description of some new species: Journal of Paleontology, v. 40, p. 613-634.

Brower, J.C., 1992, Cupulocrinid crinoids from the Middle Ordovician (Galena Group, Dunleith Formation) of northern Iowa and southern Minnesota: Journal of Paleontology, v. 66, p. 99-128.

Brower, J.C., 1994, Camerate crinoids from the Middle Ordovician (Galena Group, Dunleith Formation) of northern Iowa and southern Minnesota: Journal of Paleontology, v. 68, p. 570-599.

Brower, J.C., 2006, Ontogeny of the food-gathering system in Ordovician crinoids: Journal of Paleontology, v. 80, p. 430-446, doi:10.1666/ 0022-3360(2006)80[430:OOTFSI]2.0.CO;2.

Brower, J.C., and Veinus, J., 1982, Long-armed cladid inadunates, in Sprinkle, J., ed., Echinoderm Faunas from the Bromide Formation (Middle Ordovician) of Oklahoma: University of Kansas Paleontological Contributions, Monographs, v. 1, p. 129-144.

Callaway, C., 1877, On a new area of upper Cambrian rocks in South Shropshire, with a description of new fauna: Quarterly Journal of the Geological Society of London, v. 33, p. 652-672.

Church, S.B., 1974, Lower Ordovician patch reefs in western Utah: Brigham Young University Geology Studies, v. 21, p. 41-62.

Clark, A.H., and Clark, A.M., 1915, A monograph of the existing crinoids, Volume 1, The comatulids: Bulletins of the United States National Museum, Smithsonian Institution, v. 82, p. 1-878.

Cole, S.R., 2017, Phylogeny and morphologic evolution of the Ordovician Camerata (class Crinoidea, phylum Echinodermata): Journal of Paleontology, v. 91, special issue 4, p. 815-828, doi:10.1017/jpa.2016.137.

Dattilo, B.F., 1993, The Lower Ordovician Fillmore Formation of western Utah: Storm-dominated sedimentation on a passive margin: Brigham Young University Geology Studies, v. 39, p. 71-100.

David, B., and Mooi, R., 1999, Comprendre les échinodermes: La contribution du modèle extraxial-axial: Bulletin de la Société Géologique de France, v. 170 , p. $91-101$.

David, B., Lefebvre, B., Mooi, R., and Parsley, R., 2000, Are homalozoans echinoderms? An answer from the extraxial-axial theory: Paleobiology, v. 26, p. 529555, doi:10.1666/0094-8373(2000)026 < 0529:AHEAAF > 2.0.CO;2.

Derstler, K., Guensburg, T.E., Blake, D.B., and Sprinkle, J., 2018, Arms in Camptostroma, an archaic pentaradiate echinoderm: Geological Society of America Abstracts with Programs, v. 50: doi:10.1130/abs/2018AM-324634.
Donovan, S.K., and Cope, C.W., 1989, A new camerate crinoid from the Arenig of South Wales: Palaeontology, v. 32, p. 101-107.

Durham, J.W., 1966, Camptostroma, an early Cambrian supposed scyphozoan referable to Echinodermata: Journal of Paleontology, v. 40, p. 1216-1220.

Durham, J.W., 1968, Camptostromatoids, in Moore, R.C., ed., Treatise on Invertebrate Paleontology, Part S, Echinodermata 1(2): New York, New York, and Lawrence, Kansas, Geological Society of America (and University of Kansas), p. S627-S631.

Edwards, C.T., 2019, Links between early Paleozoic oxygenation and the Great Ordovician Biodiversification Event (GOBE): A review: Paleoworld, v. 28 , p. 37-50, doi:10.1016/j.palwor.2018.08.006.

Foerste, A.F., 1938, Echinodermata, in Resser, C.E, and Howell, B.F., eds., Lower Cambrian Olenellus Zone of the Appalachians: Geological Society of America Bulletin, v. 49, p. 195-248.

Geissman, J.W., Bowring, S.A., and Babcock, L.E., compilers, 2018, Geological Time Scale, v. 5.0: Geological Society of America, https://doi.org/ 10.1130/2018 (accessed January 2019).

Guensburg, T.E., 1984, Echinodermata of the Middle Ordovician Lebanon Limestone, central Tennessee: Bulletins of American Paleontology, v. 86, p. $1-100$.

Guensburg, T.E., 1992, Paleoecology of hardground encrusting and commensal crinoids, Middle Ordovician, Tennessee: Journal of Paleontology, v. 66, p. $129-147$.

Guensburg, T.E., 2010, Alphacrinus new genus and the origin of the disparid clade: Journal of Paleontology, v. 84, p. 1209-1216, doi:10.2307/ 40925993.

Guensburg, T.E., 2012, Phylogenetic implications of the oldest crinoids: Journal of Paleontology, v. 86, p. 455-461, doi:10.2307/41480208.

Guensburg, T.E., and Sprinkle, J., 1994, Revised phylogeny and functional interpretation of the Edrioasteroidea based on new taxa from the Early and Middle Ordovician of western Utah: Fieldiana, Geology, new ser., no. 29, p. $1-43$.

Guensburg, T.E., and Sprinkle, J., 2003, The oldest known crinoids (Early Ordovician, Utah), and a new crinoid plate homology system: Bulletins of American Paleontology, v. 364, p. 1-43.

Guensburg, T.E., and Sprinkle, J., 2007, Phylogenetic implications of the Protocrinoidea: Blastozoans are not ancestral to crinoids: Annales de Paléontologie, v. 93, p. 277-290, doi:10.1016/j.annpal.2007.09.005.

Guensburg, T.E., and Sprinkle, J., 2009, Solving the mystery of crinoid ancestry: New fossil evidence of arm origin and development: Journal of Paleontology, v. 83, p. 350-364, doi:10.1666/08-090.1

Guensburg, T.E., and Sprinkle, J., 2017, New evidence of early hybocrinid tegmens; Phylogenetic implications: Geological Society of America Abstracts with Programs, paper (49-2). doi:1130/ABS/2017-ne291462.

Guensburg, T.E., Mooi, R., Sprinkle, J., David, B., and Lefebvre, B., 2010, Pelmatozoan arms from the mid-Cambrian of Australia: Bridging the gap between brachioles and arms? Comment: There is no bridge: Lethaia, v. 43, p. 432-440, doi:10.1111.j.1502-3931.2010.00220.x.

Guensburg, T.E., Blake, D.B., Sprinkle, J., and Mooi, R., 2016, Crinoid ancestry without blastozoans: Acta Palaeontologica Polonica, v. 61, p. 253-266, doi:10.4202/app.00211.2015.

Hall, J., 1847, Description of the organic remains of the Lower Division of the New York System: New York Geological Survey, Natural History of New York, Paleontology, v. 1, p. 1-338.

Heinzeller, T., and Welsch, U., 1994, Crinoidea, in Harrison, F.W., and Chia, F.-S., eds., Microscopic Anatomy of the Invertebrates, Volume 14, Echinodermata: New York, Wiley-Liss, p. 9-148.

Hintze, L.F., 1973, Lower and Middle Ordovician stratigraphic sections in the Ibex area, Millard County, Utah: Brigham Young University Geology Studies, v. 20 , p. $3-36$

Hyman, L., 1955, The Invertebrates, Volume 4, Echinodermata: New York, McGraw-Hill, $761 \mathrm{p}$.

Jaekel, O., 1901, Über Carpoideen, eine neue Klasse von Pelmatozoen: Zeitschrift der Deutschen Geologischen Gesellschaft, v. 52, p. 661-677.

Jobson, L., and Paul, C.R.C., 1979, Compagicrinus fenestratus, a new Lower Ordovician inadunate crinoid from North Greenland: Rapport Gronlands Geologiske Undersogelse, v. 91, p. 71-81.

Kammer, T.W., Sumrall, C.D., Zamora, S., Ausich, W.I., and Deline, B., 2013 , Oral region homologies in Paleozoic crinoids and other plesiomorphic pentaradial echinoderms: PLoS ONE, v. 8, p. 1-16, doi:10.1371/journal.pone. 0077989.

Kolata, D.R., 1982, Camerates, in Sprinkle, J., ed., Echinoderm Faunas from the Bromide Formation (Middle Ordovician) of Oklahoma: University of Kansas Paleontological Contributions, Monographs, v. 1, p. 170-205.

Lane, N.G., 1970, Lower and Middle Ordovician crinoids from west-central Utah: Brigham Young University Geology Studies, v. 17, p. 3-17.

Meek, F.B., and Worthen, A.H., 1865, Description of new species of Crinoidea, etc., from the Palaeozoic rocks of Illinois and some of the adjoining states: Academy of Natural Sciences of Philadelphia, Proceedings, v. 17, p. 143-155. 
Miller, J.S., 1821, A Natural History of the Crinoidea or Lily-shaped Animals, with Observations on the Genera Asteria, Euryale, Comatula, and Marsupites: Bristol, UK, Bryan and Company, $150 \mathrm{p}$.

Mooi, R., and David, B., 1998, Evolution within a bizarre phylum: Homologies of the first echinoderms: American Zoologist, v. 38, p. 965-974.

Mooi, R. and David, B., 2000, What a new model of skeletal homologies tells us about asteroid evolution: American Zoologist, v. 40, p. 326-339, doi:10.1093/icb/40.3.326.

Mooi, R., David, B., and Wray, G., 2005, Arrays in rays: Terminal addition in echinoderms and its correlation with gene expression: Evolution and Development, v. 7, p. 542-555, doi:10.1111/j.1525-142X.2005.05058.x.

Moore, R.C., 1962, Ray structures of some inadunate crinoids: University of Kansas Paleontological Contributions, Echinodermata, article 5, p. 1-47.

Moore, R.C., 1978, Order Disparida, in Moore, R.C., and Teichert, C., eds., Treatise on Invertebrate Paleontology, Part T, Echinodermata 2(2): Boulder, Colorado, and Lawrence, Kansas, Geological Society of America (and University of Kansas Press), p. T520-T574.

Moore, R.C., and Laudon, L.R., 1943, Evolution and classification of Paleozoic crinoids: Geological Society of America, Special Papers, v. 46, p. 1-153.

Nichols, D., 1960, The histology and activities of the tube-feet in Antedon bifida: Quarterly Journal of Microscopical Science, v. 101, p. 105-117.

Öpik, A.A., 1934, Ristnacrinus, a new Ordovician crinoid from Estonia: Tartu Ülikooli Geoloogia Instituut Toimetused, v. 40, p. 1-7.

Parsley, R.D., 1982, Eumorphocystis, in Sprinkle, J., ed., Echinoderm Faunas from the Bromide Formation (Middle Ordovician) of Oklahoma: University of Kansas Paleontological Contributions, Monographs, v. 1, p. 280-288.

Parsley, R.D., and Mintz, L.W., 1975, North American Paracrinoidea (Ordovician: Paracrinozoa, new, Echinodermata): Bulletins of American Paleontology, v. 68 , no. 288 , p. $1-115$.

Paul, C.R.C., 1968, Macrocystella Callaway, the earliest glyptocystitid cystoid: Palaeontology, v. 11 , p. $580-600$.

Paul, C.R.C., and Smith, A.B., 1984, The early radiation and phylogeny of echinoderms: Biological Reviews, v. 59, p. 443-481.

Pompeckj, J.F., 1896, Die Fauna des Cambrium von Tejrovic und Skrej in Böhmen: Jahrbuch der Kaiserlich-königlichen Geologischen Reichsanstalt, v. 45, p. 495-614.

Roux, M., and Lambert, P., 2011, Two new species of stalked crinoids from the northeastern Pacific in the genera Gephyrocrinus and Ptilocrinus (Echinodermata, Crinoidea, Hyocrinidae): Effects on ontogeny and variability on hyocrinid taxonomy: Zootaxa, v. 2825, p. 1-54.

Ruedemann, R., 1933, Camptostroma, a lower Cambrian floating hydrozoan: Proceedings of the United States National Museum, v. 82, p. 1-13.

Sheffield, S.L., and Sumrall, C.D., 2019a, A re-interpretation of the ambulacral system of Eumorphocystis (Blastozoa, Echinodermata) and its bearing on the evolution of early crinoids: Palaeontology, v. 62, p. 163-173, doi:10.1111/pala.12396.

Sheffield, S.L., and Sumrall, C.D., 2019b, The phylogeny of the Diploporita: A polyphyletic assemblage of blastozoan echinoderms: Journal of Paleontology, doi:10.1017/pa.2019.2, 13 p.

Sinclair, G.W., 1945, Some Ordovician echinoderms from Oklahoma: American Midland Naturalist, v. 34, p. 707-716.

Smith, A.B., and Jell, P.A., 1990, Cambrian edrioasteroids from Australia and the origin of starfishes: Memoirs of the Queensland Museum, v. 28, p. 715-778.

Sprinkle, J., 1973, Morphology and evolution of blastozoan echinoderms: Museum of Comparative Zoology, Harvard University, Cambridge, Special Publications, p. 1-283.

Sprinkle, J., 1982a, Hybocrinus, in Sprinkle, J., ed., Echinoderm Faunas from the Bromide Formation (Middle Ordovician) of Oklahoma: University of Kansas Paleontological Contributions, Monographs, v. 1, p. 119-128.

Sprinkle, J., 1982b, Large-calyx cladid inadunates, in Sprinkle, J., ed., Echinoderm Faunas from the Bromide Formation (Middle Ordovician) of Oklahoma: University of Kansas Paleontological Contributions, Monographs, v. 1 , p. $145-169$.

Sprinkle, J., 1985, New edrioasteroid from the middle Cambrian of western Utah: University of Kansas Paleontological Contributions, Papers, v. 116, p. 1-4.

Sprinkle, J., and Sumrall, C.D., 2015, New edrioasterine and asterocystitid (Echinodermata: Edrioasteroidea) from the Ninemile Shale, central Nevada: Journal of Paleontology, v. 89, p. 346-352, doi:10.1017/jpa.2014.29.
Strimple, H.L. 1953, A new species of Archaeocrinus from Oklahoma: Journal of Paleontology, v. 27, p. 604-606.

Strimple, H.L., and McGinnis, M.R., 1972, A new camerate crinoid from the Al Rose Formation, Lower Ordovician of California: Journal of Paleontology, v. 46, p. $72-74$

Sumrall, C.D., and Waters, J., 2012, Universal elemental homology in glyptocystitoids, hemicosmitoids, coronoids, and blastoids: Steps toward phylogenetic reconstruction in derived Blastozoa: Journal of Paleontology, v. 86, p. 956-972, doi:10.2307/23353782.

Swofford, D.L., 2003, PAUP*, Phylogenetic Analysis Using Parsimony (*and Other Methods), Version 4: Sinauer Associates, Sunderland, Massachusetts, http://phylosolutions.com/paup-test/.

Taylor, M.E., and Miller, J.F., 1989, Late Cambrian and Early Ordovician stratigraphy and biostratigraphy, southern House Range ('Ibex Area'), Utah, in Taylor, M.E., ed., Cambrian and Early Ordovician Stratigraphy and Paleontology of the Basin and Range Province, Western United States, International Geological Congress, 28th, Field Trip Guidebook T125: Washington, DC, American Geophysical Union, p. 45-58.

Termier, H., and Termier, G., 1949, Hiérarchie et corrélations des caractères chez les Crinoidea Fossils: Service Carte Géologie l'Algérie, Bulletin Séries 1, Paléontologie, no. 10, pt. 1, p. 1-90.

Ubaghs, G., 1953, Notes sur Lichenoides priscus Barrande, éocrinoïde du Cambrien moyen de la Tchécoslovaquie: Bulletin de l'Institut Royal des Sciences Naturelles de Belgique, v. 29, p. 1-24.

Ubaghs, G., 1963, Rhopalocystis destombesi n. g., n. sp., éocrinoïde de l'Ordovicien inférieur (Trémadocien supérieur) du Sud marocain: Notes et Mémoires du Service Géologique du Maroc, v. 23, p. 25-45.

Ubaghs, G., 1967b, Le genre Ceratocystis Jaekel (Echinodermata, Stylophora). University of Kansas Paleontological Contributions, Papers, v. 22, p. 1-16.

Ubaghs, G., 1968 ("1967a"), Eocrinoidea, in Moore, R.C., ed., Treatise on Invertebrate Paleontology, Part S, Echinodermata 1(2): New York, New York, and Lawrence, Kansas, Geological Society of America (and University of Kansas), p. S455-S495.

Ubaghs, G., 1969, Aethocrinus moorei Ubaghs, n. gen. n. sp, le plus ancien crinoïde dicyclique connu: University of Kansas Paleontological Contributions, Papers, v. 38, p. 1-25.

Ubaghs, G., 1978, Skeletal morphology of fossils crinoids, in Moore, R.C., and Teichert, C., eds., Treatise on Invertebrate Paleontology, Part T, Echinodermata 2(1): Boulder, Colorado, and Lawrence, Kansas, Geological Society of America (and University of Kansas), p. T58-T216.

Ulrich, E.O., 1925, New classification of the Heterocrinidae: Canadian Geological Survey, Memoirs, v. 138, p. 82-106.

Walcott, C.D., 1883 ("1884"), Descriptions of new species of fossils from the Trenton Group of New York: New York State Museum of Natural History, Annual Report 35, p. 207-214.

Warn, J.M., 1982, Long-armed disparid inadunates, in Sprinkle, J., ed., Echinoderm Faunas from the Bromide Formation (Middle Ordovician) of Oklahoma: University of Kansas Paleontological Contributions, Monographs, v. 1, p. $77-89$.

Warn, J.M., and Strimple, H.L., 1977, The disparid inadunate superfamilies Homocrinacea and Cincinnaticrinacea (Echinodermata: Crinoidea), Ordovician-Silurian, North America: Bulletins of American Paleontology, v. 72, p. $1-138$.

Wright, D.F., 2017, Bayesian estimation of fossil phylogenies and the evolution of early to middle Paleozoic crinoids (Echinodermata): Journal of Paleontology, v. 91, special issue 4, p. 799-814, doi:10.1017/jpa.2016.141.

Zamora, S., Lefebvre, B., Hosgör, I., Franzen, C., Nardin, E., Fatka, O., and Alvaro, J.J., 2015, The Cambrian edrioasteroid Stromatocystites: Systematics, palaeogeography, and palaeobiology: Geobios, v. 48, p. 417-426, doi:10.1016/j.geobios.2015.07.004.

Zhao, Y., Sumrall, C.D., Parsley, R.D., and Peng, J., 2010, Kailidiscus, a new plesiomorphic edrioasteroid from the Kaili biota of Guizhou Province, China: Journal of Paleontology, v. 84, p. 668-680, doi:10.1666/09-159.1.

Zhu, X.-J., Zamora, S., and Lefebvre, B., 2014, Morphology and paleoecology of a new edrioblastoid (Edrioasteroidea) from the Furongian of China: Acta Palaeontologica Polonica, v. 59, p. 921-926, doi:10.4202/app.2012.0116.

Accepted: 3 October 2019 